\title{
OTORITAS DAN GERAKAN KEAGAMAAN DAENGGURU: STUDI SEJARAH ISLAMISASI DI SULAWESI SELATAN
}

\author{
Mustari Bosra \\ Universitas Negeri Makasar \\ Email: bosra_mustari@yahoo.com
}

\begin{abstract}
This paper is about the Islamization movement of the kingdoms in South Sulawesi, sointegrated sara 'is into a social institution called pangadereng (Bugis) angadakkang (Makassar). To ensure the upholding of Islamic law, which has been integrated into the social system, a religious bureaucracy (Islam) known aswas formed sara'. The royal bureaucratic officials who handle this institution, from the central level to the village or village level are called parewa sara ', which in this study uses the term daengguru. This integration pattern was developed in almost all Islamic kingdoms in South Sulawesi. Adat has its own field and sharia controls its own field. One another should not disturb each other. When the King of Bone La Maddarremmeng was about to confront Islam and customs, he was opposed by all parties. When Arung Matowa Wajo declared a strong Islamization, he was also evicted from his position.
\end{abstract}

Keywords: Islamization, Religious Movement, Daengguru, South Sulawesi

\begin{abstract}
Abstrak
Tulisan ini tentang gerakan Islamisasi terhadap kerajaan-kerajaan di Sulawesi Selatan maka diintegrasikanlah sara' ke dalam pranata sosial yang disebut pangadereng (Bugis) angadakekang (Makassar). Untuk menjamin tetap tegaknya syariat Islam yang telah terintegrasi ke dalam pranata sosial itu dibentuklah lembaga birokrasi keagaman (Islam) yang dikenal sebagai sara'. Pejabat birokrasi kerajaan yang menangani lembaga ini, dari tingkat pusat hingga desa atau kampung disebut parewa sara', yang dalam kajian ini digunakan istilah daengguru. Pola integrasi yang seperti itulah yang dikembangkan dalam hampir semua kerajaan Islam di Sulawesi Selatan. Adat memiliki bidangnya sendiri dan syariat menguasai bidangnya sendiri. Antara satu dengan yang lainnya tidak boleh saling ganggu menggangu. Ketika Raja Bone La Maddarremmeng hendak mempertentangkan antara Islam dengan adat kebiasaan, dia dimusuhi oleh semua pihak. Ketika Arung Matowa Wajo mencanangkan Islamisasi yang kaaffah, dia pun digusur dari kedudukannya.
\end{abstract}

Kata Kunci: Islamisasi, Gerakan Keagamaan, Daengguru, Sulawesi Selatan

\section{PENDAHULUAN}

Sulawesi Selatan adalah salah satu daerah yang umat Islamnya terkenal sangat taat menjalankan agamanya. ${ }^{1}$ Hasil ini tidak lepas dari proses sejarah masa lalu yang sangat panjang -dalam konteks ini ditentukan antara tahun 1914-1942. Dalam kurun waktu itu telah terjadi trasformasi sosial yang sangat signifikan di kalangan umat Islam, yakni bergesernya dan

\footnotetext{
${ }^{1}$ Mustaqim Pabbajah, Religiusitas dan Kepercayaan Masyarakat Bugis-Makasar, dalam Jurnal al-Ulum Vol. 12 No. 2 Tahun 2012, 397-418; Jubba, dkk., Kompromi Islam dan Adat pada Praktik Keagamaan Muslim Bugis di Sulawesi Selatan, dalam JSW: Jurnal Sosiologi Walisongo Vol. 2 No. 2 Tahun 2018, 137-148; Sabara Nuruddin, Islam dalam Tradisi Masyrakat Lokal di Sulawesi Selatan, dalam Mimikri: Jurnal Agama dan Kebudayaan Vol. 4 No. 1 Tahun 2018, 50-67.
} 
terdistribusikannya tanggung jawab pengembangan dan pemeliharaan Islam dari para "ulama parewa sara" yang secara struktural berada dalam lingkaran birokrasi kerajaan ke tangan para "ulama-bebas".

Beberapa hasil riset tentang Islam di Sulawesi Selatan seperti riset Armin, ${ }^{2}$ Wekke, ${ }^{3}$ Darmawijaya \& Abbas, ${ }^{4}$ Sakka, ${ }^{5}$ Abdullah, ${ }^{6}$ dan Rahmawati ${ }^{7}$ menunjukkan, sejak Islam diterima oleh penduduk dan dijadikan agama resmi beberapa kerajaan besar seperti Gowa, Luwu dan Bone pada awal abad ke-17, secara struktural, agama itu berada di bawah tanggung jawab langsung dari para bangsawan penguasa. Hal ini mengakibatkan tidak bisa dipisahkan antara pemelihara pemerintahan dengan pengatur ritual keagamaan. Keduanya berasal dari sumber sosial yang sama yaitu para bangsawan. ${ }^{8}$ Kondisi ini terjadi disebabkan oleh raja yang telah diislamkan para ulama, mengkonversi dari kerajaan non Islam menjadi kerajaan Islam, seperti kerajaan Gowa." Jadi, "kekuasaan pusat" yang "di-Islam-kan" atau dengan kata lain, "Islam masuk" melalui "pintu gerbang istana". Dengan demikian, maka proses Islamisasi lebih lanjut berpusat pula di “istana." Para bangsawan penguasa yang diwakili oleh para parewa sara' secara struktural adalah pemegang otoritas dan penanggung jawab pengembangan Islam.

Namun, keadaan tersebut mengalami perubahan secara drastis dan dramatis sejak awal hingga pertengan abad ke-20. Bermula dari keberhasilan pemerintah Hindia Belanda menaklukkan dan menguasai secara penuh semua kerajaan lokal merdeka ${ }^{10}$ di Sulawesi Selatan pada tahun 1905-1906. ${ }^{11}$ Hingga pada akhirnya pembekuan beberapa kerajaan, seperti Bone ${ }^{12}$

${ }^{2}$ Mardi Adi Armin, Islam \& Tradisi Budaya di Sulawesi Selatan, dalam Jurnal Adabiyah Vol. 10 No. 2 Tahun 2010, 237-251.

${ }^{3}$ Ismail Suardi Wekke, Islam dan Adat: Tinjauan Akulturasi Budaya dan Agama dalam Masyarakat Bugis, dalam Analisis: Jurnal Studi Keislaman Vol. 13 No. 1 Tahun 2013, 27-56.

${ }^{4}$ Darmawijaya \& Irwan Abbas, Sejarah Muhammadiyah di Sulawesi Selatan 1926-1942, dalam Jurnal Lektur Keagamaan Vol. 12 No. 2 Tahun 2014, 465-478.

${ }^{5}$ La Sakka, Historiografi Islam di Kerajaan Bantaeng, dalam Jurnal al-Qalam Vol. 20 No. 1 Tahun 2014, 6574.

${ }^{6}$ Anzar Abdullah, Islamisasi di Sulawesi Selatan dalam Perspektif Sejarah, dalam Paramita: Historical Studies Journal Vol. 26 No. 1 Tahun 2016, 86-94.

${ }^{7}$ Rahmawati, Perspektif Baru dalam Proses Penyebaran Islam di Kerajaan Bone Sulawesi Selatan Indonesia pada Abad ke 17, dalam Rihlah: Jurnal Sejarah dan Kebudayaan Vol. 3 No. 1 Tahun 2015, 80-87.

8 Taufik Abdullah, Pengantar, dalam Taufik Abdullah, Agama dan Perubahan Sosial, V-XV, (Jakarta: Rajawali Pers, 1983), xi.

${ }^{9}$ Puji Siswadi, Politik Islamisasi Kerajaan Gowa-Tallo Terhadap Tiga Kerajaan Tellumpoccoe (Bone, Soppeng, Wajo) pada Abad 17, dalam Rihlah: Jurnal Sejarah dan Kebudayaan Vol. 4 No. 1 Tahun 2016, $120-140$.

${ }^{10}$ Menurut G.J. Resink, pada periode akhir abad ke-19, terdapat sejumlah kerajaan yang masih berstatus sebagai negeri contractueele bondgenooten, yakni negeri sekutu yang secara hukum setara dengan negeri Hindia Belanda. Di Sulawesi Selatan, kerajaan-kerajaan yang masih memiliki status seperti itu, adalah Gowa, Bone, Luwu, Wajo dan Soppeng. Lihat: Lapian (1997: 216-217)

${ }^{11}$ Penomena perang penaklukan kerajaan-kerajaan merdeka dan penandatanganan korteverklaring pada awal abad XX itu bukan hanya terjadi di Sulawesi Selatan. Dalam waktu yang hampir bersamaan, pemerintah Hindia Belanda telah melancarkan pula perang yang sama terhadap kerajaan-kerajaan merdeka yang tersebar di Sulawesi Tengah, antara lain: Kerajaan Moutong, lihat: Kambay (1997); Kerajaan Sigi, lihat: Lamarauna (1997); Kerajaan Mori, lihat: Hasan dan Mahid (1997); dan kerajaan Luwuk-Banggai, lihat: Siojang (1997).

68 |Falasifa, Vol. 11 Nomor 2 September 2020 
dan Gowa ${ }^{13}$ yang kemudian diikuti pengangkatan pejabat birokrasi kolonial menyebabkan tercorengnya pranata sosial tradisional yang disebut pangadakkang (Makassar) atau pangadereng (Bugis) ${ }^{14}$ pada satu sisi dan tersingkirnya sebagian bangsawan penguasa tradisional dari lingkaran birokrasi pemerintahan Hindia Belanda pada sisi lainnya. Mereka yang tersingkir itu, bukan hanya para pemangku adat yang bergelar somba, mangkau, karaeng, opu, arung, gallarrang, dan sebagainya, tetapi termasuk di dalamnya para ulama yang menduduki berbagai jabatan parewa sara'. Seperti: Daengta Kaliya, Daengimang dan Daengguru

\section{PEMBAHASAN}

\section{Parewa Sara' dan Adat-Istiadat Warisan Pra-Islam}

Sebagai konsekuensi logis atas terjadinya Islamisasi terhadap kerajaan-kerajaan di Sulawesi Selatan maka diintegrasikanlah sara' ke dalam pranata sosial yang disebut pangadereng (Bugis) angadakkang (Makassar). Untuk menjamin tetap tegaknya syariat Islam yang telah terintegrasi ke dalam pranata sosial itu dibentuklah lembaga birokrasi keagaman (Islam) yang dikenal sebagai sara'. Pejabat birokrasi kerajaan yang menangani lembaga ini, dari tingkat pusat hingga desa atau kampung disebut parewa sara', yang dalam kajian ini digunakan istilah daengguru untuk mewakilinya, sebagaimana telah dijelsakan terdahulu.

Sebagai bagian dari birokrasi pemerintahan, struktur organisasi lembaga sara' disesuaikan dengan strutur organisasi lembaga ada. ${ }^{15}$ Petta Kali(Bugis)/Daengta Kaliya(Makassar) adalah pejabat birokrasi keagamaan (Islam) tertinggi dalam suatu kerajaan. Dia mengepalai lembaga sara' secara keseluruhan. Berdasarkan struktur, petta kali atau daengta kaliya sejajar — dalam arti berdampingan — dengan raja, berkedudukan di Ibukota kerajaan. Di tingkat distrik yang pada umumnya adalah kerajaan bawahan ${ }^{16}$ lembaga sara' dikepalai oleh imang bate atau imang limpo, ${ }^{17}$ yang sering juga disebut guru pangpawa, berdampingan dengan kepala distrik atau raja bawahan yang disebut gallarrang, karaeng, arung, anang, dan sebagainya. Di tingkat desa atau kampung, lembaga sara' dikepalai oleh imang desa atau imang kampung yang sering juga disebut guru dan disapa sebagai daengguru, berdampingan dengan kepala desa atau kepala kampung, yang disebut daeng, punggawa, lo'mo, dan sebagainya. Dalam menjalankan tugasnya, pejabat-pejabat

${ }^{12}$ Kerajaan Bone dibekukan setelah kalah berperang dengan tentara pemerintah Hindia Belanda pada akhir tahun 1905 dan baru direhabilitasi kembali dengan status zelfbestuur di bawah pimpinan raja bone ke-32, Andi Mappanyukki pada tahun 1930. Lihat: Patunru dkk (1995: 268).

${ }^{13}$ Kerajaan Gowa dibekukan sejak rajanya I Makkulau Daeng Serang Karaeng Lembang Parang Sultan Husain Tumenanga ri Bundukna meninggalkan kerajaanya pada awal tahun 1906 dan direhabitasi kembali dengan status zelfbestuur di bawah pimpinan raja Gowa ke-35, I Mangimangi Daeng Mattutu Karaeng Karaeng Bontonompo Sultan Muhammad Tahur Muhibuddin pada tahun 1936. Lihat: Patunru (1993: 121).

${ }^{14}$ Tentang norma yang mengatur sistem sosial di Sulawesi Selatan itu, lebih lanjut lihat uraiannya dalam bab II. Untuk kepentingan praktis, maka dalam penyebutan berikutnya, hanya digunakan salah satu di antara pangadakkang atau pangadereng.

${ }^{15}$ Dimaksudkan dengan lembaga $a d a$ ' dalam hal ini adalah lembaga birokrasi kekuasaan kerajaan yang menangani masalah pemerintahan secara umum.

${ }^{16}$ Oleh pemerintah Hindia Belanda, daerah atau kerajaan bawahan yang agak besar dan penduduknya banyak diberi status distrik, sedangkan yang lebih kecil diberi satatus onder-distrik.

${ }^{17}$ Dalam beberapa kerajaan, terdapat pejabat parewa sara' di tingkat kerajaan atau daerah bawahan yang memakai gelar kali, Di Wajo, misalnya terdapat dua daerah bawahan yang pejabat parewa sara'-nya disebut kali, yaitu kali Belawa dan kali Pammana. Di Gowa, sebelum perang perang Makassar, terdapat juga seorang kali bawahan, yaitu kali Bontoala. 
keagamaan tersebut tadi dibantu oleh beberapa orang pejabat parewa sara' lainnya yang disebut katte, amele, bidala, dan doja.

Dengan terbentuknya lembaga sara', maka terdapatlah dua macam lembaga dalam sistem pemerintahan kerajaan Islam di Sulawesi Selatan, yaitu ada' dan sara'. Dalam batas kewenangannya masing-masing, kedua lembaga memiliki kedudukan yang sama. Hal itu dapat dilihat dalam ungkapan lontara, sebagaimana dikutip Ramlah Hakim.

'Mappakarajai sara'e ri ade'e. Mappekalebbi'i ade'e ri sara'e. Temmakeullei massarang sara'e sibawa ade'e. Temmakkullei ade'e narusa' taro bicarana sara'e. Temmakkullei sara'e narusa' taro bicaranna ade'e. Pusai ade'e ri taro bicaranna, masappai ri bicaranna sara'e. Pusai sara'e ri taro bicaranna, massappai ri bicaranna ade'e. Tempeddingngi siapusa-pusang ia dua, ade'e sibawa sara'e. Tempeddingi sirasa' taro bicaranna dara'e sibawa ade'e. (Aritinya: Sara' menghormati ada'. Ada' menghormati sara'. Ada' dan sara' tidak boleh dipisahkan. Ada' tidak boleh membatalkan putusan sara'. Sara' tidak boleh membataklan putusan ada'. Apabila ada' tidak dapat memutuskan suatu perkara, maka ia mencari bantuan kepada sara'. Apabila sara' tidak dapat memutusakan suatu perkara, maka ia meminta bantuan kepada ada'. Ada' dan sara' tidak boleh sesat menyesatkan. Tidak boleh saling membatalkan keputusan antara ada' dan sara)." 18

Menurut Noorduyn, ${ }^{19}$ yang membedakan antara pejabat ada' dari pejabat sara' adalah tugasnya. Pejabat ada' bertugas melaksanakan urursan pemerintahan secara umum. Sedangkan pejabat sara' betanggung jawab dalam hal pelaksanaan ibadat, zakat, pengawasan dan pemakmuran masjid, serta pelaksanaan perkawinan dan kewarisan.

Sama halnya para pejabat $a d a$ ', yang biasanya berasal dari keturunan para bangsawan, para pejabat sara' pun pada umumnya direkrut dari keturunan para bangsawan. ${ }^{20}$ Mengapa para pejabat parewa sara' sebaiknya dipilih dari golongan bangsawan? Dato Ri Bandang ${ }^{21}$ ketika diangkat menjadi kali di Wajo, guna menata lembaga sara' di sana, menjelaskan sebagai berikut:

'Tae kueloreng katte ri $W$ ajo ranrenge, temmabusung tettong ri mimbara'e mappangaja, nasaba arollata ri Nabitta Muhammad saw, apa' wija arung tosa Nabitta. Wija bate lompoesa muala bilala, temmabusung tettong ri tengngana masigi'e mangobbireng deceng appalang, pammase, nasaba arolatta $r i$ sahaba'na Nabitta, apa' wija arung muto sahaba'na Nabitta. Arung mabbicaraesa muala amele, temmabusung majello-jello ri laleng masigi ri olona puang ri Wajo, matui tudangnge. Dara arungngesa muala pampawa ri limpoe. (Artinya: Yang saya kehendaki menjadi katte di Wajo ialah ranreng supaya tidak durhaka berdiri di atas mimbar memberi nasehat, sebagai ikutan kita kepada Nabi Muhammad saw yang juga adalah keturunan bangsawan. Saya berharap agar turunan batelompo yang kamu angkat menjadi bilala, supaya tidak merasa durhaka berdiri di tengah-tengah masjid mengajak orang kepada kebaikan, pahala, dan rahmat. Hal ini sebagai ikutan kepada sahabat-sahabat Nabi yang mereka juga adalah keluarga bangsawan. Saya berharap agar arung mabbicara yang kamu angkat menjjadi amele agar tidak

\footnotetext{
${ }^{18}$ Lihat: Hakim (1991: 92).

${ }^{19}$ Lihat Noorduyn (1964: 93).

${ }^{20}$ Meskipun demikian perlu ditambahkan bahwa persyaratan kebangsawanan dalam rekruitmen pejabat sara' tidaklah bersipat mutlak, sebagaimana halnya pejabat $a d a^{\prime}$. Itulah sebabnya sehingga di beberapa kerajaan, jabatan petta kali seringkali diduduki oleh ulama yang tidak berdarah bangsawan murni, bahkan sering pula berasal dari luar.

${ }^{21}$ Dikutip dari Lontara Arung Betteng La Tompi dan berdasarkan wawancara Umar Syihab dengan Andi Parenrengi pada tahun 1996. Lihat: Syihab (1988: 183-184).
}

70 |Falasifa, Vol. 11 Nomor 2 September 2020 
merasa durhaka jika menunjuk-nunjuk di dalam masjid mengatur tempat duduk di muka arung Wajo. Saya berharap agar keturunan bangsawan yang kamu angkat menjadi guru pampawa (imang) pada setiap limpo."22

Alasan Dato ri Bandang untuk memilih parewa sara' dari keluarga bangsawan diterima baik oleh Arung Matowa Wajo dan segenap anggota dewan hadat kerajaan. Sebagai realisasinya, diangkatlah pejabat parewa sara di masing-masing limpo yang berasal dari keluarga bangsawan. Sebagai contoh di Limpo Bettempola, La Mallalengeng (kemenakan ranreng Bettempola) diangkat menjadi katte, La Palla Daeng Pasampo (kemenakan pilla Wajo) diamngkat menjadi bilala, dan La Sake (anak arung mabbicara Ujungkalakkang) diangkat menjadi guru pampawa (imang limpo). ${ }^{23}$ Pejabat-pejabat sara' secara hoirisontal adalah pendamping renrang Bettempola dan secara vertikal berada di bawah komando petta kali Wajo.

Sebagaimana yang terjadi di kerajaan Wajo, rekruitmen pejabat sara' di kerajaan-kerajan lainnya di Sulawesi Selatan pada periode awal juga diambil dari keturunan para bangsawa. Dan, sejak saat itu, diwarisikanlah jabatan sara' secara turun temurun, oleh pejabat lama kepada anak cucu atau keluarga dekatnya, meskipun tidak secara mutlak, karena pejabat sara' dituntut memiliki "pengetahuan agama yang memadai." Hal ini diperlukan dalam rangka mengembang tugasnya yang sangat berat, yakni sebagai penanggungjawab penyebaran, pengembangan, pelaksanaan, dan pemelihara kelestarian agama Islam.

Sehubungan dengan pembentukan lembaga sara' dan pengangkatan parewa sara' di hampir semua kerajan di Sulawesi Selatan, timbullah persoalan tentang bagaimana mendamaikan antara syariat Islam yang bersumber dari wahyu Ilahi dengan adat istiadat yang besumber dari pangadakeang.

Seperti telah dikemukakan terdahulu bahwa jauh sebelum menerima agama Islam, masyarakat Sulawesi Selatan telah melaksanakan interaksi sosial-politiknya berdasarkan nilainilai dan norma-norma yang telah diwarisi turun temurun yang disebut pangadakekang. Nilai-nilai dan norma-norma yang merupakan landasan bagi adat kebiasaan masyarakat tersebut tentu saja tidak berdasarkan wahyu yang datang dari Allah Yang Maha Tahu. Oleh karena itu, maka patut diduga bahwa adat kebiasaan masyarakat itu berbeda dan bahkan bertentangan dengan ajaran Islam (syariat) yang mereka terima kemudian. Kalau demikian, maka di antara keduanya mesti terjadi konflik. Kelihatannya memang demikian, tetapi konflik antara adat kebiasaan dan syariat di Sulawesi Selatan adalah konflik dalam pengertian suatu proses yang bersifat dialektik yang mengarah pada tercapainya sintesis di antara keduanya.

Untuk menghindari konflik yang bersifat frontal, sejak proses awal islamisasi, para pengajur Islam pertama tidak mempersoalkan hal-hal yang berkaitan dengan adat kebiasaan. Ketika Dato ri Bandang berusaha mengislamkan masyarakat di kerajaan Gowa, dato ri Bandang dikabarkan hanya menuntun mereka mengucapkan dua kalimat syahadat dan mengajurkan agar mereka tidak makan daging babi.

Sehubungan dengan larangan makan babi ini, tersebarlah suatu ceritra di masyarakat yang sampai sekarang masih didapati tentang proses pengislaman dua orang penguasa daerah

${ }^{22}$ Lihat: Syihab (1988: 184).
${ }^{23}$ Lihat: Syihab (1988: 185).

Falasifa, Vol. 11 Nomor 2 September 2020| 71 
bawahan dalam wilayah inti kerajaan Gowa. Keduanya bersaudara, yang kakak berkuasa di Kassi $^{24}$ sehingga disebut Daeng Kassi, sedangkan yang adik berkuasa di Kajenjeng sehingga disebut Daeng Kajengjeng. Dalam waktu bersamaan, Daeng Kassi dan Daeng Kajengjeng dipanggil raja Gowa Sultan Alauddin menhadap ke Istana untuk dipertemukan dengan Dato ri Bandang dalam rangka pengislaman mereka. Dalam pertemuan tersebut, Dato ri Bandang memperkenalkan Islam secara sederhana dan mengajak mereka menerima Islam dengan mengucapkan dua kalimat syahadat. Keduanya menyetakan kesediannya. Tetapi, ketika Dato ri Bandang menjelaskan kepada mereka bahwa setelah mengucapkan dua kalimat syahadat, mereka tidak boleh lagi "makan babi," Daeng Kassi mengajukan permohonan agar pengislaman atas dirinya ditunda dulu sampai dendeng babi yang terlancur dibuat oleh isterinya habis. Dato ri Bandang memaklumi keadannnya, sehingga yang dituntun mengucapkan dua kalimat syahadat pada saat itu hanya Daeng Kajenjeng. Sekembali dari istana, Daeng Kassi sakit dan akhirnya meninggal dunia, sebelum dendeng babinya habis. Tidak berselang lama setelah Daeng Kassi meninggal dunia, Daeng Kajengjeng juga wafat. Oleh karena, Daeng Kassi meninggal dunia sebelum menerima Islam, maka mayatnya dikuburkan membujur ke arah timur dan barat. Sedangkan, Daeng Kajenjeng wafat setelah memeluk Islam, maka jenazahnya dikuburkan secara Islam, membujur ke arah utara dan selatan. ${ }^{25}$

Dari ceritra pengislaman Daeng Kajenjeng tersebut tanpaklah bahwa Dato ri Bandang sebagai penganjur Islam pertama belumlah mengajarkan Islam secara kaaffah (utuh dan menyeluruh) kepada seorang mualaf. Yang dipentingkan oleh Dato ri Bandang adalah kesediaan seseorang menerima Islam sebagai agamanya dengan meyakini bahwa tidak ada tuhan yang patut disebah selain Allah SWT serta meyakini bahwa Muhammad saw adalah Nabi utusan Allah. Dan, sebagai bukti ke-Islam-annya, dia dilarang memekan babi.

Dato ri Bandang tentu saja berharap bahwa para pendakwah Islam yang datang kemudianlah yang menyampaikan Islam yang kaaffah dan menyempurnakan proses pengislaman yang dilakukannya. Tetapi, karena segera setelah proses awal pengislaman tersebut, raja yang telah mengkonversi kerajaan menjadi kerajaan Islam mengambil alih tanggung jawab penyebaran dan pengembangan Islam, maka islamisasi secara kaaffah tidak dapat berjalan sesuai yang diharapkan. Raja sebagai penanggung jawab pemerintahan yang didasarkan atas pangadakkang dan sekaligus penanggung jawab penyebaran dan pengembangan Islam, tentu saja berusaha menjaga agar tidak terjadi konflik antara pangadakkang dan syariat.

\footnotetext{
${ }^{24}$ Kampung Kassi yang sudah disebutkan dalam put not ... bab satu, diduga banyak orang sebagai salah satu di antara sembilan negeri asal kerajaan Gowa. Menurut mereka, kalau bukan penulis lontara (yang pertama) salah menulisakan "si" menjadi "li" maka pembaca lontara (yang pertama) salah membaca, "si" dibaca "li." Boleh jadi dugaan itu benar, sebab Kalling sebagai salah satu di antara sembilan negeri asal kerajaan Gowa yang disebut dalam lontara (mungkin salinan dari lontara pertama yang salah tulis atau dibaca secara tidak benar), sampai saat ini memang belum diketahui di mana lokasinya, karena nama negeri itu tidak terdapat dalam wilayah daerah inti kerajaan Gowa yang membentang dari Lakiuang di sebelah barat hingga Saumata di sebelah timur.

${ }^{25}$ Baik kuburan Dang Kajenjeng yang terdapat di kampung Kajenjeng maupun kuburan Daeng Kassi yang terdapat di kampun Kassi, keduanya masih dikeramatkan dan setiap tahun diziarahi banyak orang. Penziarahnya, bukan hanya berasal dari kampung Kassi/kajengjeng dan sekiratnya, tetapi juga ada yang berasal dari luar, seperti Kabupaten Maros.
}

72 |Falasifa, Vol. 11 Nomor 2 September 2020 
Untuk itu, maka diintergrasikanlah sara' ke dalam pangadakkang. Dengan demikian adat kebiasaan dan syariat, dua hal yang kelihatannya bertentangan disatukan dalam satu wadah yang bernama pangadakekang.

Pola integrasi yang seperti itulah yang dikembangkan dalam hampir semua kerajaan Islam di Sulawesi Selatan. Adat memiliki bidangnya sendiri dan syariat menguasai bidangnya sendiri. Antara satu dengan yang lainnya tidak boleh saling ganggu menggangu. Ketika Raja Bone La Maddarremmeng hendak mempertentangkan antara Islam dengan adat kebiasaan, dia dimusuhi oleh semua pihak. Ketika Arung Matowa Wajo mencanangkan Islamisasi yang kaaffah, dia pun digusur dari kedudukannya.

Jadi, meskipun agama Islam telah menjadi agama resmi kerajaan dan sara' telah diterima menjadi salah satu unsur pangadakkang serta lembaga sara' telah pula dibentuk dari tingkat pusat sampai ke kampung-kampung, namun belumlah dapat dikatakan bahwa ajaran Islam yang meliputi aqidah, ibadah, dan muamalat ${ }^{26}$ telah berjalan secara sempurna di tengah-tengah kehidupan masyarakat, termasuk dalam istana kerajaan. Hingga awal abad ke-20, penerimaan Islam sebagai agama resmi kerajaan belumlah terlalu banyak mengubah kepercayaan, kaidahkaidah kemasyarakatan, dan nilai-nilai budaya yang telah ada sebelumnya. Mattulada menjelaskan bahwa:

Apa yang dibawah Islam pada mula datangnya, hanyalah urusan-urusan ubudiah (ibadah) dan tidak mengubah lembaga-lembaga dalam kehidupan masyarakat yang ada, utamanya lembaga-lembaga sosial yang menyangkut kehidupan politik sesuai dengan pangadereng. ... sasaran utama para penyebar Islam (pada permulaan datangnya) hanya Sendi-sendi kehidupan masyarakat dengan nilai-nilai kesusilaan tertuju kepada soal iman dan kebenaran tauhid.

Kurangnya perubahan yang ditimbulkan oleh penerimaan Islam sebagai agama resmi kerajaan dan menandakan bahwa sistem penyebaran Islam yang ditempuh oleh para penganjur Islam adalah sistem "akomodatif." Kebiasaan-kebiasaan lama, termasuk ritual-ritual agama animisme dan dinasme yang dianut masyarakat sebelum Islam masih tetap dipertahankan. Hanya saja, kebiasaan-kebiasaan lama itu diberi warna Islam atau akidahnya "di-Islam-kan."

Para penganjur Islam periode awal tentu berharap bahwa pengiintegrasian ajaran Islam ke dalam pangadakkan demikian pula lembaga parewa saralah yang kelak akan mengadakan perubahan atau pembaruan. Tetapi kenyataan sejarah tidak demikian. Raja sebagai penanggungjawab penegmbangan dan perluasan Islam, memilih tetap mempertahankan keseimbangan antara adat dan Islam.

Upaya mempertahankan keseimbangan sosial inilah yang menyebabkan Syek Yusuf ditolak oleh raja Gowa ketika hendak mengadakan pembaruan Agama Islam. Dalam lontara, disebutkan:

"Tallu passala napala Tuangta Salamaka mange ri Sombaya ri Gowa. Uru-uruna nipamari anginunga ballo sarru, ganna ruana nipamari ammadaka, gannatalluna nipamari abotoroka.

\footnotetext{
${ }^{26}$ Munurut Syaltut (1966) ajaran Islam hanya meliputi aqidah dan syariah. Sedangkan menurut putusan Tarjih Muhammadiyah, ajaran Islam meliputi aqidah, ibadah, muamalat, dan akhlak, lihat Himpunan Putusan Tarjih Muhammadiyah.
} 
Otoritas Dan Gerakan Keagamaan Daengguru..

Nakanamo Sombaya takkullea nipamari angnginunga ballo sarru, kapunna nipamari angnginunga ballo sarru taenamo tubarani. Takkuletongangngai nipamari ammadaka, kapunna nipamari ammadaka taenamo tupanrita. Takkulle tongangngai nipamari abbotoroka, kapunna nipamari abbotoroka taenamo baratu." (Ada tiga hal yang dimohon Tuangta Salamaka kepada raja Gowa. Pertama dia meminta agar peminuman tuak diberantas. Kedua, dia meminta agar pemadatan diberantas. Ketiga,dia meminta agar perjudian diberantas. Raja Gowa menjawab: peminuman tuak tidak boleh diberantas, sebab kalau tidak ada peminum tuak maka tidak ada orang berani, Pemadatan tidak boleh diberantas sebab kalau tidak ada orang yang minum madat maka tidak ada orang pandai. Perjudian tidak boleh diberantas, sebab kalau tidak ada orang yang berjudi maka tidak pajak perjudian).”

Oleh karena permintaannya ditolak maka Syekh Yusuf meninggalkan Gowa menuju Banten. Dia beranggapan bahwa kegiatan dakwah yang sedianya akan dilaksanakan di kerajaan Gowa itu tidak akan berjalan mulus karena bertentangan dengan kehendak penguasa.

Untuk menjaga keharmonisan, penguasa tradisional, pada umumnya tidak menginginkan adanya perubahan yang dilakukan secara radikal. Mereka berharap memlalui pengintegrasian Islam ke dalam pangadakkang-lah, proses sosialisasi enkulturasi Islam berlangsung secara berangsur-sngur. Itulah sebabnya, sehingga raja Bone La maddaremmeng yang mengadakan pembaruan Isalam secara radikal di kerajaannya ditentang oleh para pembesar kerajaan, termasuk ibunya sendiri. La Maddaremmeng menganggap bahwa tidak ada artinya kita menganut agama Islam dan menjadikannya sebagai agama resmi kerajaan kalau ajaran Islam tidak diimplementasikan dan diaktualisasikan dalam kehidupan masyarakat. Untuk itu, dia berusaha meluruskan akidah umat Islam di kerajaannya dengan jalan memberantas kemusyrikan. Dia memerintahkan agar pohon-pohon keramat di tebang, saukang (tempat pemujaan kepada tuhan-tuhan selain Allah) dirobohkan. Dia juga berusaha menerapkan ajaran persamaan derajat manusia ${ }^{27}$ dengan jalan memerintahkan kepada para bangsawan untuk memerdekakan budak-budaknya. Pendek kata, dia menghendaki agar adat-adat istiadat yang tidak sesuai dengan Islam ditinggalkan dan sayariat Islam dijalankan secara murni dan konsekuen.

Informasi lain tentang bagaimana perpaduan dan percampuran antara Islam dengan adat istiadar di Sulawesi Selatan dapat kita peroleh dari artikel Noorduyn, "Sejarah Agama Islam di Sulawesi Selatan." Dalam segala seluk beluk perhubungan antara adat dan agama Islam dapat ditemukan bahwa sejak penerimaan Islam, perbedaan yang nyata antara agama Islam dengan kehidupan lainnya telah tampak. Tetapi, sejak permulaan pula, orang sudah menjaga agar perbedaan itu tidak menimbulkan pertentangan dan tidak mengganggu sistem kemasyarakatan. Untuk itu, maka hanya sedikit sekali adat kebiasaan yang mutlak dikenakan larangan agama dan kesatuan masyarakat tetap dipelihara di bawah kekuasaan raja-raja, sehingga dalam praktekknya sejak dahulu, Islam terjalin erat dengan adat kebiasaan. Hal seperti iru terjadi, karena peng-Islam-an sendiri dilakukan dan ditentukan oleh kekuasaan raja-raja, sehingga agama baru itu tidak pernah lepas dari pengawasan mereka.

${ }^{27}$ Menurut ajaran Islam, semua manusia sama di sisi Tuhan. Yang membedakan antara satu dengan yang lainnya hanyalah ketakwaannya kepada Allah. Lihat Al-Quran Surah (Al-Hujuraat: 13).

74 |Falasifa, Vol. 11 Nomor 2 September 2020 
Adat istidat yang pada dasarnya bertentangan dengan Islam, tetapi oleh Noorduyn disaksikan dipraktekkan oleh umat Islam Sulawesi Selatan antara lain adalah: berkorban dalam rumah-rumah yang disebut sankang ${ }^{28}$ pada waktu-waktu tertentu, seperti setelah panen padi, memberi hormat kepada arwah-arwah nenek moyang di tempat-tempat tertentu, termasuk dalam lingkungan istana, dan memberikan persembahan di pohon-pohon besar dan di tempattempat keramat. Selain itu, dalam daerah kerajaan Gowa, ada golongan yang beranggapan bahwa tanah Gowa sama derajatnya dengan tanah Arab. Apa-apa yang ada di Arab ada juga di Gowa. Misalnya air zamzam diyakini ada di sumur keraton Gowa yang lama di kampung Bonto Biraeng, dekat makam Sultan Hasanuddin, Mereka menimba air zamzam pada tanggal 9 Zulhijjah. Baitullah diyakini ada di gunung Bawakaraeng, pinggir sebelah timur Gowa, sehingga kalau sembahyang mereka menghadap ke timur. Tentang naik haji ke Makkah, mereka beranggapan bahwa naik haji bagi orang Gowa sudah tidak wajib karena Syek Yusuf Tuangta Salamaka telah menghajikan orang Gowa. Oleh karena itu ziarah ke makam Tuangta Salama demikian pula ziarah ke gunung Bawakaraeng, nilainya sama dengan ibadah haji ke Makkah.

Dari informasi Chabot dan Noorduyn di atas, tampaklah bahwa masyarakat Sulawesi Selatan yang nota bene adalah Muslim, masih mencampur baurkan antara adat istiadat dan agama. Dan, oleh sara', keadaan seperti itu didiamkan, tidak boleh diberantas begitu saja, sebab hal itu adalah bagian dari pangadakkang, yang sara' tidak berwenang mencampurinya. Dalam rangka proses dakwah, oleh parewa sara', upacara-upacara seperti telah disebutkan di depan diganti dengan upacara "assuro maca". "Upacara ini diyakini oleh masyarakat sebagai persembahan kepada orang yang telah meninggal dunia. Tetapi oleh daengguru "di-islam-kan" dengan diisi oleh do'a keselamatan baik kepada arwah yang bersangkutan maupun untuk keluarga dari arwah yang bersangkutan.

Upacara assuro maca ini terutama dilakukan masyarakat, pada waktu ditimpa musiba kematian. Untuk kepentingan memberi sajian kepada keluarga yang baru meninggal, assuro macam biasanya dilakukan tiga kali sehari, yakni setiap waktu makan: pagi, siang, dan malam. Biasanya berlangsung hingga hari ke tujuh. Sesudah hari ketujuh dilewatkan assuro maca hanya diadakan pada waktu waktu tertentu, misalnya hari ke-30, 40, 100, dan setahun setelah kematiannya. Daengguru biasanya bertindak sebagai tukang baca.

Sebelum mengundang daengguru, keluarga yang akan mengadakan upacara assuro maca, lebih dulu menyiapkan sajian berupa makanan, yang terdiri atas nasi lengkap dengan lauk pauknya, kue-kue, dan buah-buahan kalau ada. Setelah segalanya disiapkan keluarga yang bersangkutan mengundang daengguru untuk untuk datang ke rumahnya membaca do'a keselamatan. Setelah dipersilakan oleh tuang rumah yang punya hajat, duduklah daengguru di hadapan sajian yang akan dipersembahkan tadi. Daengguru kemudian membaca do'a selama

\footnotetext{
${ }^{28}$ Rumah kecil yang sengaja dibangun di tempat-tempat yang dianggap keramat, seperti di dekat pohon besar, di sudut-sudut kampung, di dekat kuburan, sebagai tempat pemujaan. Rumah tersebut merupakan rumah panggung yang lantainya terbuat dari bambu atau papan, tetapi tidak memakai dinding.

${ }^{29}$ Upacara ini dapat dilaksanakan setiap saat, terutama dalam rangjka menolak bala, atau lepas darui suatu kesusahan sebagai tanda syukur. Tetapi yang terutama sekali pada waktu keluarga ditimpa musibah kematian. Unruk keselamatan si mati, keluarga mengadakan upacara assuro maca mulai hari pertama hingga hari ke tujuh, dan seterusnya hari ke30, ke-40, ke-100, hingga satu tahun.
} 
beberapa menit. Selesai membaca doa, daengguru dipersilakan memakan sajian yang disiapkan dan telah dibacakan do'a untuknya. Dengan demikian do'a dan halusnya makanan diyakini sampai kepada almarhum/alamarhumah.

Beberapa adat istiadat yang kelihatannya sangat bertentangan dengan syariat Islam itu dapat tetap terpelihara karena ditoleransi oleh daengguru atau didiamkan karena dianggap bukan kewenangannya. Secara garis besar, kewenang daengguru menurut pangadakkan, ada dua yaitu: sebagai kadi mahkamah syariat dan sebagai penanggung jawab urusan agama.

Sebagai kadi mahkamah syariah, parewa sara' yang dalam hal ini petta kali atau aengta kaliya bertugas menyelesaikan berbagai perselisihan dan perkara yang timbul di kalangan umat Islam. ${ }^{30}$ Dan, sebagai penanggung jawab urusan agama Islam, parewa sara' bertugas menjamin terlaksananya ajaran Islam di tengah-tengah kehidupan umat Islam, yang oleh Pat Badrun ${ }^{31}$ dirinci sebagai berikut: (1) memimpin pelaksanaan salat berjamaah dan rangkaiannya, (2) menjadi amil zakat di tempat domisilinya masing-masing, (3) melaksanakan atau memimpin pelaksanaan akad nikah, (4) memberikan nasehat yang berkaitan dengan perkawinan, perceraian, dan pembagian warisan, (5) memimpin upacara-upacara sosail keagamaan yang ditradsikan, seperti akikah, khitanan, khataman, syukuran, dan peringatan hari-hari besar Islam, (6) memimpin penyelenggaraan pengurusan jenazah, (7) melaksanakan pemotongan hewan untuk sesuatu hajat, (8) memelihara dan memakmutrkan rumah-rumah ibadah, (9) mengoordinasi guru-guru dan membimbing guru-guru mengaji, (9) menggairahkan kehidupan beragama masyarakat, dan (10) menjadi da'i atau muballigh.

\section{Kadi dan Yurisdiksinya}

Secara normatif, syariat meliputi seluruh aspek kehidupan Muslim. Tetapi, penerapannya dalam hukum positif kerajaan-kerajaan Islam di Sulawesi Selatan masih sangat terbatas pada aspek yang menyentuh kehidupan pribadi dan keagamaan saja, yakni masalahmasalah keluarga dan yang berkaitan dengan kewarisan dan wakaf. Ketentuan-ketentuan syariat lainnya belumlah berlaku secara positif dalam kehidupan sosial kemasyarakatan. Menurut H. J. De Graaf, ${ }^{32}$ keadaan seperti itu berlaku secara umum di kerajaan-kerajaan Islam di Asia Tenggara. Yurisdiksi keagamaan para pejabat agama kerajaan sangat terbatas pada aspek ajaran Islam tertentu saja.

Keterbatasan yurisdiksi, dialami juga oleh lembaga peradilan agama di Sulawesi Selatan, yang disebut kali. Kali hanya berwenang memeriksa dan memutus perkara yang berkaitan dengan masalah perkawinan, perceraian dan pembagian warisan. Perkara lainnya, terutama yang berkaitan dengan masalah jinayat (pidana) sama sekali diluar kewenangannya. Dan, hukum pidana Islam memang tidak diberlakukan di Sulawesi Selatan, meskipun kerajaannya dinyatakan sebagai kerajaan Islam atau paling tidak Islam dijadikan sebagai agama resmi kerajaan.

Sebelum menganut agama Islam, masyarakat Bugis-Makassar telah memiliki hukum adat yang diatati dan terpelihara sebagai tata aturan di tengah-tengah masyarakat, Tata aturan yang

\footnotetext{
${ }^{30}$ Perlu dijelaskan bahwa perkara yang diputuskan mahkamah yang dipimpin daengta kaliya belumlah pinal. Putusannya masih bisa dikoreksi oleh mahkamah yang diketuai oleh raja dengan beranggotakan dewan hadat kerajaan yang di dalamnya termasuk daengta kaliya sendiri.

${ }^{31}$ Lihat: Badrun (1991: 50-51).

${ }^{32}$ Lihat: de Graaf (1989: 18-19)

76 |Falasifa, Vol. 11 Nomor 2 September 2020
} 
terdiri atas empat unsur, sebagaimana telah disebutkan terdahulu itu, disebut pangadakan. Setelah agama Islam diterima sebagai agama resmi kerajaan, diintegrasikanlah sara' sebagai unsur pangadakkang yang kelima. Dengan demikian, secara konsepsional, hukum Islam meskipun sangat terbatas, hanya meliputi hukum perkawinan dan kewarisan saja - telah diterima sebagai hukum yang berlaku positif di tengah-tengah masyarakat.

Sebagai hukum positif, maka hukum Islam memerlukan lembaga peradilan. Untuk itu, maka menyusul pengakuan secara konsepsional tersebut, dibentuklah "pengadilan sara" sebagai lembaga yang memproses dan memutus perkara-perkara yang timbul sehubungan dengan pemberlakuan hukum Islam secara terbatas tersebut.

Sebagai pejabat tertinggi dalam lembaga parewa sara', daengta kaliya secara ex officio adalah ketua pengadilan syara' di puasat kerajaan. Dalam menjalankan tugasnya, dia dibantu oleh pejabat parewa sara' lainnya, seperti katte dan imang bate atau kali bawahan.

Pada umumnya, dalam satu kerajaan hanya terdapat satu pengadilan sara'. Tetapi seiring dengan pertumbuhan penduduk, beberapa kerajaan membentuk lagi lembaga pengadilan sara' di daerah bawahannya, yang juga dipimpin oleh seorang pejabat parewa sara' yang disebut kali. Di kerajaan Wajo misalnya, selain petta kali Wajo terdapat lagi kali di dua daerah bawahan yaitu, kali Belawa dan kali Pammana. Tetapi, berbeda dari Wajo, di kerajaan Sidenreng dan Rappang, terdapat hanya seorang kali untuk kedua kerajaan tersebut, yaitu kali Sidenreng.

Sepanjang kurun waktu penelitian ini, bahkan hingga terbentuknya Pengadilan Agama yang berada di bawah naungan Departemen Agama RI pada tahun 1958, lembaga pengadilan sara' masih tetap bejalan secara efektif. Bagaimana lembaga pengadilan sara' memeriksa dan memutus perkara yang diajukan kepadanya, berikut dikemukakan salah satu putusan kali Belawa yang termuat dalam berita acara putusan no. 12 tahun 1936, ${ }^{33}$ sebagai berukut:

Pada tanggal 9 Februari 1936, kali Belawa Haji Maratang menetapkan pembagian tanah warisan, peninggalan salah seorang penduduk Belawa yang bernama La Beddu. Perkara warisan ditangani kali, karena adanya gugatan yang diajukan oleh Guru Supu bin La Baddu (anak lakilaki La Baddu dari isterinya yang pertama) terhadap sawah dan kebun seluas 3,30 ha, peninggalan La Baddu yang dikuasai oleh Cinnong binti La Baddu (anak perempuan La Baddu dari isterinya yang kedua yang bernama Takampo). ${ }^{34}$ Dalam putusannya, kali Belawa menetapkan pembagian sawah dan kebun yang sisengketakan tersebut berdasarkan hukum kewarisan Islam yang dikenal sebagai paraele. Berdasarkan pembagian paraele tersebut maka Takampo (isteri yang masih hidup ketika La Baddu meninggal dunia) memperoleh 1/8 X 3,30 = 0,41 ha; Guru Supu bin La Baddu memperoleh 1,93 ha; dan Cinnong memperoleh 0,96 ha.

Kasus perkara perceraian yang ditangani kadi pengadilan sara', terjadi di Gowa pada tahun 1941. Maryam Daeng Minne, isteri pertama Muhammad Daeng Matutu (Daengta Gallarrang Tombolo) mengajukan gugatan cerai terhadap suaminya, kepada Daengta Kaliya ri

${ }^{33}$ Arsip tersebut difotocopy dari Syihab (1988: 423-424) dan dilampirkan dalam disertasi ini (Lihat lampiran 6).

${ }^{34}$ Sawah dan kebun tersebut dikuasai Cinnong binti La Baddu, karena setalah Labaddu meninggal dunia pada tahun 1932, sawah dan kebunnya itu dikuasai oleh Takampo. Dan, setelah takampo meninggal dunia pada tahun 1934, maka penguasaan atas sawah dan kebun tersebut beralih kepada anaknya Cinnong.

Falasifa, Vol. 11 Nomor 2 September 2020| 77 
Otoritas Dan Gerakan Keagamaan Daengguru.

Gowa. Alasan pengajuan gugatannya ialah suaminya beristeri terus menerus hingga sudah lebih dari 10 kali. Karena banyaknya isterinya Muhammad Daeng Matutu, menyebabkan Maryam Dang Minne selaku isteri pertama diterlantarkan dalam arti tidak lagi diberi nafkah lahir dan batin. Berdasarkan pengaduan tersebut Daengta Kaliya menyelenggarakan pengadilan sara'. Daengta Kaliya memperhadapkan kedua belah pihak, dan mendatangkan saksi-saksi yang diperlukan. Dalam pengadilan tersebut, Muhammad Daeng Matutu menolak menjatuhkan talak kepada isterinya. Akan tetepi karena tuntutan Maryam Daeng Minne dinilai memenuhi ketentuan-ketentuan yang telah ditetapkan sara' serta sesuai "taklik talak" "35 yang diucapkan oleh Muhammad Daeng Matutu ketika menikahi Maryam daeng Minne pada tahun 1912, maka Daengta Kaliya memutuskan "talak pasah"36 atas Muhammad Daeng Matutu kepada isterinya Maryam Daeng Minne.

Beberapa kasus penyelesaian perkara di atas, membuktikan bahwa hukum syariat Islam dalam aspek yang sangat terbatas memang secara nyata berlaku secara positif di daerah-daerah zelfbestuur dan daerah-daearah adat gemeenschap. Kelihatannya pemerintah kolonial Belanda di Sulawesi Selatan tidak mencampuri masalah peradilan agama yang dilaksanakan secara turun temurun oleh masing-masing kerajaan.

Kebijaksanaan pemerintah Hindia Belanda dalam hal pengadilan agama memeng tidak ada yang ruang lingkup berlakunya meliputi selurh Indonesia. Pengaturan pengadilan agama yang ditetapkan pemerintah Hindia Belanda berdasarkan staatsblad 1882 N0 152 yang kemudian dilengkapi dengan staatsblad 1937 No. 116 dan 610 hanya berlaku untuk Jawa dan Madura. Sedangkan staatsblad 1937 No. 638 dan 639 hanya mengatur pengadilan agama di Kalimantan Selatan dan Kalimantan Timur. ${ }^{37}$

Pengadilan agama di daerah-daerah lainnya, ada yang diatur secara tersendiri, seperti Palembang dan ada pula yang sama sekali belum diatur. Perkara yang menyangkut urusan agama di daerah yang belum diatur diserahkan kepada landraad (pengadilan umum) ataupun kepada pengadilan adat. Untuk daerah Sulawesi Selatan pengadilan agama dianggap masuk ke dalam pengadilan adat.

Di Sulawesi Selatan, kewenangan mengadili perkara-perkara keagaman oleh pejabat parewa sara' berlangsung hingga terbentuknya Pengadilan Agama Propensi dan Kabupatenkabupaten secara resmi pada tahun 1958.

\section{Koordinator dan Pelaksana Pendidikan Islam}

Salah satu kewajiban parewa sara' yang merupakan bagian dari tugas pengembangan dan pembinaan agama Islam adalah mengoordinasi penyelenggaraan pendidikan agama Islam. Sebelum gerakan pembaruan di bidang pendidikan dilaksanakan, pendidikan Islam di Sulawesi Selatan secara garis besar dapat dibagi ke dalam dua tingkatan, yaitu pendidikan dasar yang

\footnotetext{
${ }^{35}$ Suatu perjanjian perkawinan, yang diucapkan suami setelah akad nikah, yang antara lain berisi berisi pernyataan bahwa manakala suami meninggalkan isterinya tiga bulan berturut tanpa memberi nafkah lahir dan batin, dan isterinya keberatan atas hal itu dan mengadukan halnya kepada kadi, maka kadi berhak menjjatuhkan talak pasah atas nama suami kepada isterinya.

${ }^{36}$ Talak yang dijatuhkan hakim atas nama suami kepada isterinya, karena si suami keberatan menalak istrinya.

${ }^{37}$ Lihat: Rahim (1998: 160).

78 |Falasifa, Vol. 11 Nomor 2 September 2020
} 
disebut mangngaji korang (mengaji Al-Quran) dan pendidikan lanjuitan yang disebut mangngaji kitta (mengaji kitab). Uraian berikut memberikan gambaran secara umum tentang kedua macam lembag itu.

\section{Mngngaji Korang}

Atas persetujuan, Imang Kampung atau guru seseorang (laki-laki atau perempuan) yang memiliki keahlian membaca Al-Quran dan keterampilan mengajar dapat menyelenggarakan mangngaji korang di rumahnya atau di masjid (musala). Pendidikan Islam tingkat dasar ini diperuntukkan bagi anak-anak yang berusia antara antara 7-14 tahun. Lamanya proses pendidikan tidak ditentukan, tergantung pada ketekunan dan kemampuan anak didik. Anak yang tekun dan cerdas bisa menempuh seluruh proses pendidikan kurang dari satu tahun.

Dalam lembaga pendidikan mangngaji korang ini, pelajaran dimulai dari belajar mengenal huruf hijaiyah (abjad bahasa Arab) yang disebut allepu-lepu. Tetapi, ada juga mangngaji korang yang memulai pelajarannya dari menghapal beberapa surah pendek yang dimulai dari Al-Fatihah kemudian An-Nas, Al-Falaf, Al-Ikhlas, dan seterusnya. Setelah lancar menghapal lebih kurang dua puluh surah pendek barulah pelajaran allepu-lepu dimulai.

Setelah pengenalan terhadap huruf hijaiyah dianggap mantap, murid yang bersangkutan dipindahkan ke tahap berikutnya, yaitu belajar angngijja (mengeja). Ayat-ayat yang dieja ialah ayat-ayat yang terdapat dalam surah Al-Fatihah dan surah-surah pendek dalam juz Amma. ${ }^{38}$ Sebagai contoh cara mengeja, dapat dikemukakan satu ayat dari surah Al-Fatihah, sebagai berikut:

“Lepu rate muno lam kana al, ha rate muno mim kana ham, 'albam,' dalang dapang kana du, 'alhamdu.' Lam rawa kana li, lam saddu lepa kana llaa, 'lillaa,' ha rawa kana hi, 'Iillaahi', 'alhamdu lillahi.' Ra rate kana ra, ba rawa saddu muno lam kana bbil, 'rabbil.' A'ing lepa kana 'aa, lam rate kana la, 'aala,' mim rawa muno ya kana mie, 'alaamie,' nun rate kana na, 'alaamiena.' 'Al-hamdu lillabi rabbil 'alamiena'."

Setelah proses mengeja dianggap mantap, murid dipindahkan ke pelajaran ammaca lambusu (membaca lurus) yang dimulai dari surah Al-Fatihah kemudian pindah ke surah AlBaqarah dan seterusnya sampai tamat. Dalam proses belajar ammaca lambusu ini, murid secara bertahap meningkatkan jumlah ayat yang dibacanya setiap hari. Mula-mula sekitar lima ayat dibaca sampai lancar kemudian pindah ke sekitar lima ayat berikutnya. Setelah kemampuan membacanya semakin meningkat, murid diberi kesempatan membaca satu halaman. Setelah lancar dipindahkan ke halaman berikutnya. Demikianlah seterusnya hingga, murid diberi kesempatan memperlancar dua halaman sekaligus.

Bagi, guru mangngaji korang yang memiliki kemampuan membaca dan melagukan ayat-ayat Al-Quran, biasanya menyelenggarakan pelajaran assara baca, yakni belajar tajwid dan melagukan ayat-ayat Al-Quran. Materi pelajaran yang diberikan diambil dari buku-buku tajwad atau tatacara membaca Al-Quran yang biasanya terdapat dalam bagian akhir mushab Al-Quran.

${ }^{38}$ Juz 'Amma yang dimulai dari surah An-Naba' hingga surah An-Nas ditambah surah Al-Fatihah, dikenal sebagai korang caddi (Al-Quran kecil). Sedangkan Al-Quran secara keseluruhan yang dimulai dari surah Al-Fatihah hingga surah An-Nas disebut korang lompo (Al-Quran besar).

Falasifa, Vol. 11 Nomor 2 September 2020| 79 
Kecuali mengajar membacaAl-Quran, guru mangngaji korang, biasanya membimbing juga murid-muridnya belajar tatacara berwudu, salat, dan do'a-doa pendek. Pelajaran seperti ini diberikan dalam bentuk teori dan praktek sekaligus, sebelum atau sesudah pelajaran rutin berlangsung.

Lembaga pendidikan semacam mangngaji koran sebagaimana telah dikemukakan di depan ditemukan hampir di seluruh Indonesia, sebagaimana dibambarkan Snouck Hurgronje, ${ }^{39}$ sebagai beriktu:

"Pengajian Al-Quran ini diberikan secara individual kepada para murid. Biasanya mereka berkumpil di salah satu langgar atau serambi rumah sang guru. Mereka membaca dan melagukan ayat-ayat suci di hadapan guru satu persatu di bawah bimbingannya selama $1 / 4$ atau $1 / 5$ jam. Ketika salah seorang murid menghadap guru, murid lainnya dengan suara keras mengulang bacaan kemarin atau lanjutan pelajaran yang telah diperbaiki gurnya."

Di Palembang, tugas mengajar membaca Al-Quran tertuang dalam bab Kaum, pasa 15, Undang-undang Simbur Cahaya tahun 1877 berbunji "Hendak kaum-kaum mengajar anakanak di dalam dusun mengaji dan menyurat tiada dengan pembayaran melainkan suka orang kasih." Menurut Husni Rahim, ${ }^{40}$ tugas mengajar mengaji Al-Quran di Palembang beraada di atas pundak khatib dan bilal sebagai anggota penghulu kerajaan di tingkat desa atau dusun.

Meskipun tidak tertuang dalam suatu undang-undang, sebagaimana halnya di Palembang, namun menurut ketentuan pangadakkan perewa sara' bertanggungjawab mengembangkan dan memelihara agama. Ketika pemerintah kolonial Belanda di Selayar mengadakan pendataan guru-guru agama Islam pada tahun 1932, sejumlah imang kampung tercatat sebagai guru agama. ${ }^{41}$ Tampaknya, pemerintah kolonial Belanda juga mengenakan ordonansi guru kepada guru angngaji korang. Untuk itu maka melalui pejabat parewa sara', guru angngaji korang diwajibkan melaporkan jumlah murid dan materi pelajaran yang diberikannya.

\section{Mangngaji Kitta}

Penyampaian ajaran dan nilai-nilai Islam secara melembaga dalam bentuk pendidikan mangngaji kitta di Sulawesi Selata dimulai pada tahun 1630-an oleh Sayid Ba'alwy. ${ }^{42}$ Dia adalah seorang Arab yang datang ke Gowa pada tahun 1625. Nama lengkapnya adalah Sayid Ba'alwy bin Abdullah Al-Allamatut Thahir Assagaf yang juga dikenal sebagai Seheta Tuang Karama. Setibanya di Gowa, dia dikawinkan dengan putri Sultan Alauddin, raja Gowa ke-14 yang bernama Sitti Daeng Nipati. Dia kemudian diangkat menjadi penasehat raja dan pendamping daengta kaliya dalam rangka pelaksanaan pembinaan umat Islam melalui lembaga pendidikan. Untuk itu maka dia diberi tempat khusus untuk mengajar dan menyebarluaskan ajaran agama Islam di Kampung Bontoala (sekarang berada di tengah kota Makassar). Di kampung itulah, beliau bersama murid-murid dan masyarakat pendukungnya membangun sebuah masjid yang

${ }^{39}$ Lihat: Horgronje (1924: 161).

${ }^{40}$ Lihat: Rahim (1998: 169).

${ }^{41}$ Lihat: Arsip Selayar No.

${ }^{42}$ Lihat: Hamid (1994: ??).

80 |Falasifa, Vol. 11 Nomor 2 September 2020 
menurut catatan Lontara Bilanga ri Gowa, ${ }^{43}$ diresmikan pada 10 Nopember 1635. Di Masjid Bontoala inilah Sayid Ba'alwy menyelenggarakan pendidikannya di bawah perintah dan perlindungan mertuanya, raja Gowa ke-14 Sultan Alauddin.

Bagaimana model dan sistem pendidikan yang dikembangkan Ba'alwy itu? Tidak ditemukan sumber yang dapat memberikan informasi. Lontara hanya menyebutkan bahwa Sepeninggal Sayid Ba'alwi, salah seorang murid yang juga adalah anaknya, bernama Sayid Mukhsin Karaeng Tinggimae yang melanjutkan penyelenggaraan pendidikan agama yang pernah dibina oleh Seheta Tuang Karamaka. Sayid Mukhsin Karaeng Tinggimae, selanjutnya diangkat menjadi Daenta Kaliya di Gowa. Setelah menjadi kali, dia menetap di Katangka kemudian membangun Masjid yang hingga sekarang dianggap sebagai masjid tertua di Sulawesi Selatan. ${ }^{44}$ Di Masjid itu, dia mengajar sebagaimana ayahnya Sayid Ba'alwy. Setelah meninggal dia dimakamkan di belakang mihrab masjid Katangka berdampingan dengan ibunya.

Lembaga Pendidikan Islam yang terdapat di Masjid Bontoala sendiri, setelah ditinggalkan Sayid Mukhsin Karaeng Tinggimai diteruskan oleh murid-murid Sayid Ba'alwi lainnnya, termasuk kemudian oleh cucunya yang bernama Sayid Abdul Gaffar Waliyuddin bin Sayid Mukhsin bin Sayid Ba'alwy, yang dikenal juga sebagai Daenta Kaliya di Bontoala. Bagaimana Kelanjutan Lembaga Pendidikan Islam yang pertama di Bontoala itu? Sesudah Sayid Abdul Gaffar Waliyuddin, tidak diketahui lagi. Tetapi, mangngaji kitta yang masih ditemukan di beberapa tempat di Sulawesi Selatan hingga saat ini merupakan kelanjutan dari mangaji kitta yang dirintis Sayid Ba'alwi. Abdul Rahman Getteng ${ }^{45}$ memperkirakan bahwa sistem pendidikan mangngaji kitta yang masih tersisa saat ini, belum banyak mengalami perubahan; masih sebagaimana halnya pada awal abad ke-17, saat mulai dikembangkannya di Sulawesi Selatan.

Mangngaji kitta adalah jenjang pendidikan mangngaji yang tertinggi. Materi pelajaran yang dipelajari di sini bukan lagi Al-Quran, melainkan kitab-kitab berbahasa Arab yang tidak berharakat yang disebut kitab gundul atau kitab kuning. Kandungan materi pelajarannya terdiri atas bahasa Arab, fikhi, tauhid, tasauf, dan sejarah. Berbeda dari lembaga pendidikan tingkat dasar yang hanya dibina oleh para parewa sara' yang belum berkualifikasi ulama, lembaga pendidikan Mangngaji Kitta biasanya dibina oleh seorang parewa sara' yang keulamaannya telah diakui masyarakat, seperti mangaji kitta di Barru pada akhir abad ke-19 yang dibina oleh kali Barru Anronggurunta Haji Makka, mangngaji kitta di Sppeng pada awal abad ke-20 yang dibina oleh kali Soppeng Anronggurunta Haji Ismail, dan mangngaji kitta di Sinjai pada tahun 1920-an yang dibina oleh kali Balangnipa, Anronggurunta Haji Hasan.

Berhubung tidak banyak parewa sara' yang berkapasitas sebagai ulama, maka lembaga pendidikan angngaji kitta ini sangat langka. Di Gowa misalnya, pada sekitar tahun 1920-an, parewa sara' yang terkenal menyelenggarakan pendidikan angngaji kitta, hanyalah imang distrik Kurisi yang berkedudukan di Jongaya, yang dikenal sebagai imang Jongaya, Haji Abdul Jawad Daeng Masalle. Daengta Kaliya ri Gowa sendiri, karena bukan ulama tidak menyelenggarakan

\footnotetext{
${ }^{43}$ Liha: Kamaruddin (1985/1986: 96).

${ }^{44}$ Dalam prasasti yang tergantung di depan tembok masjid tersebut tertulis masjid tertua di Sulawesi Selatan didirikan pada tahun 1605.

${ }^{45}$ Lihat: Getteng (1992: 128).
} 
Angngaji kitta. Kali yang diketahui menyelenggarakan pendidikan angngaji kitta, pada sekitar tahun 1920, antara lain: kali Balangnipa-Sinjai, Haji Muhammad Tahir, kali Barru, Haji Makka; kali Soppeng, Haji Muhammad Katu, dan kali Campalagian, Haji Abdul Hamid.

Materi pelajaran yang diberikan pada jenjang angngaji kitta ini biasanya dimulai dari pengenalan terhadap tata bahasa Arab dengan mata pelajaran yang disebut syaraf (perubahan kata) dan nahwu (tata bahasa). Menurut penelitian Abdul Rahman Getteng, ${ }^{46}$ kitab-kitab yang dipelajari dalam tahap awal ini, antara lain: kitab Syaraf Galappo, ${ }^{47}$ Al-Mutammina, Alfiyah, AlKaelani, dan Al-Jurumiyah.

Setelah murid-murid menguasai dasar-dasar bahasa Arab, barulah diajarkan kitab-kitab berbahasa Arab yang merupakan materi pendidikan angngaji kitta yang sesungguhnya, yang meliputi Fikih, Tafsir, Hadis, dan sebagainya. Kitab-kitab yang digunakan dalam tahap ini antara lain adalah kitab Syafinah Annajab untuk mata pelajaran Fikih, Tafsir Jalalain untuk mata pelajaran Tafsir, dan Al-Hadits Al-Arbain An-Nabawiyah untuk mata pelajaran Hadis. ${ }^{48}$

Oleh karena yang mengikuti pelajaran pada angngaji kitta ini pada umumnya adalah para pemuda yang telah berumur 15 tahun ke atas maka murid yang tamat dari angngaji korang, tidak serta-merta dapat terus melanjutkan pendidikannya.

Lembaga Mangaji kitta lainnya terdapat di Afdeeling Mandar, tepatnya di Distrik Campalagia, Onderafdeeling Polewali. Mangaji Kitta tersebut pada mulanya didirikan oleh Haji Abdul Hamid, kali Campalagia. Secara sangat sederhana dan hanya diikuti oleh beberapa orang murid, Haji Abdul Hamid meneyelenggarakan pengajian kitab di rumahnya. Materi pengajiannya berkisar pada pelaksanaan ibadah sehari-hari. Pengajian mengalami perkembangan setelah diambil alih pembinaannya oleh Haji Maddeppungang, seorang ulama Bugis kelahiran Bilokka, Sidenreng Rappang.

Dalam rangka mengamalkan ilmu pengetahuan yang diperolehnya selama beberapa tahu di Butta Lompoa, Haji Maddepungang dibawa oleh pamannya, Haji Abdul Kadir ke Campalagian untuk berdakwah. Dalam menjalankan dakwahnya, ia terpikat oleh seorang gadis Campalagian, anak dari Kali Campalagian, Haji Abdul Hamid. Dengan harapan, ulama muda yang berasal dari luar daerah kelak dapat melanjutkan pengajiannya, maka Haji Abdul Hamid menikahkan anak gadisnya dengan Haji Maddeppungang.

Apa yang dicita-citakan Haji Abdul Hamid terkabul juga. Menantunya, Haji Maddepungang ternyata betah tinggal di Campalagian dan bersedia meneruskan pengajian yang selama ini dibinanya. Untuk itu, maka pembinaan pengajian pun diserahkanlah kepada sang ulama muda yang disebut terakhir.

Atas dukungan dari mertuanya mangaji kitta yang diasuh Haji Maddepungang semakin hari semakin berkembang pesat. Berbarengan dengan perkembangan mangaji kitta itu, Haji Maddempungan pun semakin terkenal dan semakin dikenal. Mangngaji kitta yang dirintis oleh

\footnotetext{
${ }^{46}$ Lihat: Getteng (1994: 135).

${ }^{47}$ Semacam diktat yang menurut Getteng (1994: 135) dikarang oleh salah seorang ulama dari Sidenreng yang menggunakan nama julukan Syeh Galappo. Tetapi, menurut Jamalullail (wawancara, 2000) kitab Syaraf Galappo tersebut dikarang oleh Syehk Muhammad Galab dari Yaman. Kitab tersebut kemudian disalin ulang menjadi semacam diktat dan oleh penyalinnya disebut kitab Syaraf Galappo.

${ }^{48}$ Lihat Getteng (1994: 136-137) dan Hamid (1986: 67).

82 |Falasifa, Vol. 11 Nomor 2 September 2020
} 
Haji Maddempungan itu kini menjadi yayasan Perguruan Islam Campalagian. Yayasan perguruan Islam Campalagian adalah salah satu yayasan yang bergerak dibidang pengembangan pendidikan dan pengajaran Islam. Pada mulanya dikenal sebagai salah satu wadah pendidikan non formal. Namanya yang untuk pertama kalinya diberikan oleh masyarakat Islam pada saat itu ialah mangngaji kitta.

Pendidikan mangngaji kitta itu dirintis oleh Kiai Haji Andul Hamid, Qadhi Campalagian pada waktu itu yang didampingi oleh Kiai haji Muhammad Arsyad alias Kiai Haji Maddempungan. Nama beliau dewasa ini diabadikan pada salah satu pesantren asuhan Yayasan perguruan Islam Campalagian, yaitu: Pesantren Al Arsyadiyah. Tempat berlangsungnya kegiatan mengajar belajar adalah rumah Haji Maddempungan sendiri. Santri yang belajar pada awal tahun pertumbuhan-nya maih dapat dihitung dengan jari-jari tangan. Dalam kegiatan mengajar belajar digunakan sistim halakah atau sistim melingkar. Guru duduk, santri yang lebih duluan datang, duduk disebelah kanan ustas, seterusnya berturut-turut melingkar hingga sebelah kiri gurunya, seperti bentuk setengah lingkaran, tanpa klasifikasi.

Penerimaan santri tidak dibatasi oleh umur, tetapi oleh tingkatan kitab yang dibacanya. waktu yang digunakan antara jam 5 dan jam 10 pagi. Dan untuk sore hari, setelah shalat ashar hingga senja hari.

Lama belajarnya tidak tertentu, tanpa pungutan uang sekolah. Haji maddempungan mengajar karena Allah semata-mata. Tujuan pendidikannya adalah membentuk ulama-ulama muslim yang dapat membaca dan menulis kitab gundul. Pengetahuan dasar yang diterapkannya adalah ilmu Nahwu dan ilmu Sharaf. Jika santri-santri telah memahami dasar-dasar ilmu Nahwu dan ilmu Sharaf, maka diberikanlah kesempatan untuk membaca kitab-kitab yang tingkat kesulitan demikian pula isinya lebih tinggi.

Ilmu-ilmu yang diajarkan pada tingkatan ini, antara lain: Ilmu Tauhid, Ilmu Fiqhi, Ilmu Tafsir, Ilmu Falak dan Tarikh Islam . tahun 1930 - 1932, santri-santri yang belajar pada perguruan ini adalah putera-putera daerah ini saja. Kitab-kitab yang dipakai para santri sebagian besar wakaf Pua Golomang.

Pada tahun 1933, perguruan ini bagaikan bunga kuncup cepat berkembang, mekar semerbak harum baunya terbawa angin keseluaruh penjuru arah mata angin. Bukan masyarakat Islam Campalagian saja yang mengenal perguruan ini, bahkan masyarakat Islam yang ada di luar Campalagian pun mengenal dan mencintainya. Santri berdatangan dari luar Campalagian, yaitu: Polewali, Pare-pare, Palanro, Pangkajene Kepulauan, Sidenreng Rappang, Kalimantan dan dari pulau Masalembu Jawa Timur. Santri melimpah, puluhan bahkan sampai ratusan orang. Jumlahnya tidak diketahui dengan pasti sebab tanpa daftar hadir. Setalah masjid-masjid berkembang pesat, maka lokasi berlangsungnya kegiatan mengajar belajar dipindahkan ke Masjid Jami’ (Masjid Raya sekarang). Perpindahan dari rumah Kiai Haji Maddempungan itu terjadi dalam tahun 1934.

Bersamaan dengan pindahnya tempat belajar, dari rumah Haji Maddempungan ke Masjid Jami', seorang gurutta bernama Haji Abdul Hamid tiba di Campalagian. Hamid baru pulang dari Tanah Suci, setelah belajar di sanan lebih kurang 4 tahu. Dia ke Tanah Suci pada tahun 1930, bertepatan dengan tahun dibukanya pengajian Haji Maddempungan, Hamid kemudian 
Otoritas Dan Gerakan Keagamaan Daengguru..

menggabungkan diri dengan Maddeppungan untuk bersama-sama membina lembaga pendidikan yang telah dibangun 4 tahun lalu itu.

Selain Hamid, beberapa orang murid Maddeppungan yang belajar sejak awal seperti Muhammadiyah dan Abdul Halim telah pula memiliki kemampun untuk membantu gurunya mengajar murid yang baru masuk.

Sejak saat itu terjadilah perkembangan baru dalam lembaga pendidikan Haji Maddempungan. Murid-murid yang berusia dibawah 15 tahun mulai diklasifikasikan berdasarkan usia dan kemampuan. Dengan demikian dirintislah sistem pendidikan klasikal. Untuk tahap pertama dua kelas tingkat ibtidaiyah dibuka, yaitu kelas satu untuk yang baru dan kelas dua untuk mereka yang sudah punya dasar.

Dengan dibukanya sistem pendidikan madrasah, maka di lembaga pendidikan Haji Maddempungan terdapat dua sistem yaitu mangngaji kitta bagi yang berusia di atas 15 tahun dan madrasah bagi yang berusia dibawah 15 tahun. Sejak saat itu, murid-murid semakin hari semakin bertambah banyak, hingga gedung darurat yang dua lokal tidak mampu lagi menampungnya. Gedung dengan peralatan yang serba darurat itu hanya mampu menampung 100 orang murid, maka pada tahun 1936 didirikanlah sebuah gedung di atas tanah waqaf Kiai Haji Abd. Hamid seluas kira-kira seluas 60 X 50 meter.

Gedung tersebut dibangun atas swadaya masyarakat dalam bentuk semi permanen, terdiri dari enam lokal, berukuran 28 X 6 meter, atap seng, dinding papan dan lantai semen atau batu dilengkapi dengan alat-alat mebiler.

Tenaga pengajar yang membina Madrasah Diniyah antara lain Kiai Haji Muhammadiyah (Kepala Sekolah) dan didampingi oleh Muh. Sanusi, seorang santri dari kabupaten Barru dan ustas Muhdin dari Kabupaten Sidenreng Rappang. Ketiga orang ustas tersebut di atas mengajar karena Allah semata tanpa mengharapkan imbalan jasa dari perguruan Islam. Beliau-beliau inilah yang membina madrasah tersebut sejak tahun 1934-1936.

Untuk tahun 1936 - 1938, guru-guru yang mengajar di Madrasah Diniah binaan perguruan Islam tersebut antara lain:

1. Haji Mahmud (Qadhi Binuang)

2. Haji Hasan (Imang Ujung)

3. Abd. Halim dari pulau Masalembu

4. Ahmad Syamsuddin

5. Mahmud Yamin

Mereka itu adalah santri perguruan Islam yang berguru, tekun berhadapan dengan kitab kitab sejak tahun 1930-1937 dan tenaganya telah

dapat digunakan untuk membina dan mengajar di samping belajar.

Gedung yang dimulai pembagunannya pada pertengahan tahun 1936 dapat dimanfaatkan pada akhir tahun itu juga. Gedung tersebut membujur dari arah timur ke barat menghadap selatan. Gedung tersebut adalah lambang keemasan perguruan Islam Campalagian. Kepercayaan masyarakat terhadap hasil-hasil yang telah dicapai semakin bertambah, akan tetapi sangat disayangkan bahwa tamatan dari Madrasah Diniyah perguruan Islam pada saat itu belum mendapat Surat Tanda Tamat Belajar (STTB) atau pun ijazah terakhir.

84 |Falasifa, Vol. 11 Nomor 2 September 2020 
Santri yang telah dianggap cakap pada bidang studi: Ilmu Nahwu,Ilmu Sharaf serta dianggap telah memiliki perbendaharaan bahasa Arab yang banyak. Atas persetujuan ustas, santri-santri tersebut dialihkan ke tingkat pengajian pondok pesantren untuk mempelajari ilmuilmu agama yang lebih mendalam lagi, misalnya saja Ilmu Tafsir, Hadits, Tauhid, Balaghah, Ilmu Mantiq, Ilmu Falak, dan ilmu-ilmu pengetahuan lain.

Ulama-ulama yang berhasil ditelorkan perguruan Islam pada saat itu tersebar ke manamana. Ada yang kembali ke kampung halamannya sendiri untuk mengabdi di sana, seperti Imang Laboso juga ada yang diutus ke salah satu daerah untuk mengembangkan ajaran Islam di sana, antara lain: Ustas Baharuddin Muhammadiyah diutus ke Matangnga Kecamatan Sumarorong. Pada tahun 1938 ulama-ulama yang juga turut melaksankan tugas yang suci itu antara lain: Kiai Haji Abd. Kadir, Imang Masjid Patoke di kecamatan Polewali, Muhammad Arsyad, Ampo Arisi, Imang Masjid Biring Tasi, Manding Kecamatan Polewali. Beliau inilah yang berhasil mengIslamkan semua penduduk berketurunan Toraja di Madatte, Desa Darma dalam tahun 1940. PengIslaman tersebut diabadikan dalam pemberian nama kampung tersebut, "Sallang Baru".

Puncak keemasan perguruan Islam pada periode ini, yaitu dari tahun 1948-1954. Jalan pelajaran sangat lancar dan jauh lebih dibanding dengan tahun-tahun sebelumnya. Kegiatan belajar mengajar berjalan secara mantap, secara efisien dan efektif dibawa asuhan para ustas yang mengajar dengan lillahi taala semata. Tenaga-tenaga pengajar yang mengabdi pada saat itu adalah mereka yang pernah bertekun berhadapan kitab-kitab gundul mangngaji kitta di bawah asuhan Kiai Haji Maddempungan dari tahun 1930-1937.

Kecuali melalui pendidikan mangngaji kitta, para ulama tradisionalis yang terikat dalam birokrasi kerajaan pun berusaha menggandeng penguasa adat membina kader-kader pengganti melalui madrasah. Ada dua madsah yang didirikan oleh penguasa birokrasi kerajaan bekerja sama dengan para ulama pejabat parewa sara', yaitu:

\section{Madrasah Amiriyah Bone dan Madrasah Islahuddin Gowa}

Stelah lebih kurang 23 tahun dibekukan pemerintah kolonial Hindia Belanda (19051930), kerajaan Bone dihidupkan kembali pada tahun pada tahun 1930. Yang dipilih Arung Pitue mejadi raja Bone pada waktu itu adalah Haji Andi Mappanyukki, putra raja Gowa ke-34 I Makkulau Daeng Serang Karaeng Lembangparang Sultan Hadi. Menyusul pengangakatan Haji Andi Mappanyukki sebagai raja, Haji Abdullah Hamid diangkat pila sebagai kali Bone.

Andi Mappanyukki dikenal sebagai seorang muslim yang taat dan memiliki komitmen yang tinggi untuk memajukan Islam. Tetapi, dia juga dikenal sangat tegas dan sangat kuat berpegang teguh kepada tradsi adat pangadakkan. Oleh karena itu maka dia sama sekali tidak mengizinkan Muhammadiyah masuk ki daerahnya.

Oleh karena rakyat Bone sudah sangat menghajatkan adanya lembaga pendidikan seperti yang dibina oleh Muhammadiyah, maka Andi Mappanyukki berusaha pula untuk memenuhinya. Dia berusaha mengcounter Muhammadiyah dengan jalan mendirikan lembaga pendidikan yang sama dengan yang didirikan oleh Muhammadiyah. Untuk itu maka atas nama kerajaan, Andi Mappanyukki dibantu Haji Abdul Hamid dan pembesar kerajaan lainnya mendirikan Madrasah yang dibneri nama Madrasah Amiriyah (madrsah yang berorientasi 
Otoritas Dan Gerakan Keagamaan Daengguru.

kepada pemerintah). Mereka berusaha mendatangkan guru-guru dari luar, sebagaimna halnya Muhammadiyah.

Kedatangan Assyiri dimanfaatkan sebaik-baiknya oleh Andi Mappanyukki, untuk itu maka atas dukungan dari segenap pembantu-pembantunya. Mappanyukki mengusahakan pembukaan sebuah madrasah. Sarana pendidikan, demikian pula biayanya ditanggung oleh raja, sebagai penghargaan kepada raja maka madrasah yang dibangunnya itu, oleh Assyiri diusulkan bernama Madrasah Amiriyah Bone yang berarti sekolah kerajaan Bone. Sebagai kepala sekolah ditunjuklah Abd. Azis Assyiri. Dalam menjalankan tugasnya, dia dibantu oleh seorang ulama dari Mesir yang bernama Abdul Hamid Al-Mishri. Dia adalah seorang ulama yang mampu menghafal 30 juz Quran.

Segera setelah pembukaan madrasah tersebut, dibanjiri oleh murid yang datang dari Bone sendiri mau pun dari luar Bone. Setelah dua tahun memimpin madrasah tersebut, Assyiri pulang ke Mesir. Dengan demikian maka kepemimpinan madrasah itu diteruskan oleh AlMishri. Hanya beberapa bulan setelah Assyiri pulang ke Mesir, raja Bone mendatangkan lagi seorang ulama yang bernama Sayid Mahmud Al-Jawad. Dia kemudian diberi tugas memimpin Madrasah Amiriyah menggantikan Al-Mishri, pimpinan sementara madrasah itu.

Mahmud Al-Jawad adalah bekas Mufti Madinah. Ketika Madinah di taklukkan oleh Ibn Saud, Al-JAwad termasuk dalam daftar orang yang hendak dihabisi. Dia diselamatkan oleh ajudannya dengan jalan dimasukkan ke dalam peti kayu kemudian dinaikkan ke kapal. Setelah tiba di atas kapal barulah dikleuarkan dari dalam peti kayu itu. Ketika sampai di Indonesia dai tinggal di Garut bersama dengan Mufti Makkah yang juga melarikan diri, Abdullah bin Shadaqah Dahlan. Dari Garut, Al-JAwad kemudian pindah ke Makassar. Di Makassarlah dia bertemu dengan muridnya Haji Muhammad Ramli yang ketika itu sudah menjadi kali di kerajaan Luwu. Atas panggilan dari Haji Muhammad Ramli, Al-JAwad pindah ke Luwu, ke suatu daerah yang bernama Cimpu. Di Cimpulah, dia dikawinkan dengan salahs eorang gadis Cimpu. Dia kemudian menetap di sana dan membuka madarasah di sana. Mengetahui keberadaanya di sana, raja Bone Andi Mappanyukki, atas persetujuan dari Haji Ramli, mengajaknya pindah ke Bone.

Sejak tahun 1935 hingga tahun 1948, Madrasah Amiriyah Islamiyah Bone dipimpin oleh Al-Jawad. Pada masa antara tahun 1935-1942, beberapa orang guru bantu didatangkan dari Jawa dan Sumatera antara lain Ustas Zainuddin Hadi, Darwis Aminy, dan Arifin Jabbar.

Kedatangan guru-guru dari Sumatera dan Jawa itulah yang mendorong terjadinya modernisasi dalam Madrasah Amiriyah. Mata pelajaran yang sebelumnya 100\% adalah pelajaran Agama, mengalami perubahan menjadi 75\% pelajaran Agama dan 25\% pelajaran umum.

Mungkin terpegaruh dengan sistem pendidikan yang dikelolah Muhammadiyah, di mana untuk tingkat sekolah menengah atas diadakan lembaga pendidikan khusus untuk mencetak guru yang diberi nama Muallimin. Dengan demikian, jenjang pendidikan di Madrasah Amiriyah telah terdiri atas Ibtidaiyah 5 tahun, Tsanawiyah 3 tahun, dan Muallimin 2 tahun.

Tak mau ketinggalan dari Bone, para bangsawan Gowa, yang kerajaannya masih dibekukan, juga berusaha mendirikan madrasah dalam rangka mengimbangi madrasah yang 
dibina oleh Muhammadiyah yang sudah berdiri di Gowa sejak tahun 1928. Dibawah komando Karaengta Tumabicarabutta, para bangsawan Gowa pun membuka Madrasah Islahuddin (sekolah untuk memperbaiki agama).

Latar belakang pemakaian nama itu, diceritrakan Syamsuddin Daeng Ngerang, murid angkatan pertama madrasah itu. Para bangsawan dan para pemuka agama Gowa melihat bahwa agama sudah dirusak oleh Muhammadiyah. Untuk itu perlu diperbaiki kembali melalui kaderkader yang dicetak oleh Madrsah Islahuddin. Sebagaimana halnya para pendiri Madrsah Amiriyah, para pendiri Madrasah Islahuddin pun berusaha mendatangkan guru-guru dari luar. Kalau Bone banyak mengambilk dari Arab, Gowa hanya mengambil dari Jawa dan Sulawesi Selatan sendiri. Salah seorang guru yang diambilnya adalah Abdullarhaman Syihab. Dia adalah seorang yang berjiwa reformis. Dian adalah tamatan Madradah yang dibina oleh Al-Jamiyah alkhairiyah Jakarta.

Satu tahun setelah Madrasah Islahuddim didirikan, kerajaan Gowa direhabilitasi kembali. Raja Gowa yang dilantik pada taun 1936, I Mangngimangi Daeng Mattutu Sultan Muhammad Thahir Muhibuddin mengambil alih tanggungjawab pembinaan madrasah tersebut. Dia kemudian mendatangkan guru-guru dari luar. Abdullah Bin Sahadaqah sengaja didatangkan dari Garut.

Raja Gowa sebenarnya menginginkan agar Abdullah bin Shadaqah Dahlanlah yang memimpin madrasah Islahuddin itu. Tetapi, karena yang bersangkutan tidak bisa menetap di Makassar maka dia hanya menjadi guru tamu yang sewaktu-waktu datang mengajar. Tanggungjawab pembinaan madrasah dipikul bersama-sama oleh guru-gurunya, yang antara lain adalah Muhammad bin Aqil, Haji Abduh Samad, Abdurrhaman Shihab, Luthan Muhammad Isa dan Jalal Ibrahim.

Murid-murid yang belajar di madrasah ini pada umuny berasal dari Gowa, Takalar dan Jeneponto. Murid-murid yang kemudian menjadi guru di tempat itu setelah kemerdekaan antara lain adalah Ali Mabhan Daeng Tojeng, Abdullah Daeng Nai dan Jamaluddin. Murid yang disebutkan pertama pada tahun 1970-an menjadi kepala kantor Departemen Agama Propinsi Sulawesi Selatan.

Baik murid-murid Madrasah Amiriyah maupun Madrasah Islahuddin dikemudian hari banyak yang menjadi ulama-ulama yang juga membuka dan mengembangkan jaringan pendidikan Islam di tempatnya. Salah seorang diantara murid angkatan pertama Madrasah Islahuddin Jongaya adalah Muhammad Ali Mabhan Daeng Tojeng, yang pada awal tahun 1970an dipercaya pemerintah menjadi Kepala Kantor Wilayah Departemen Agama Provinsi Sulawesi Selatan. Dan, salah seorang diantara murid angkatan terakhir (sebelum Jepang) Madrasah Amiriyah Bone adalah Abdul Shamad Suhaeb yang pernah menjadi Bupati Kepala Daerah Kabupaten Luwu pada tahun 1880-an.

\section{Relasi Pengurus Masjid dan Pemimpin Upacara Keagamaan}

Salat, sebagaimana sabada Nabi Muhammad saw adalah tiangnya agama Islam. ${ }^{49}$ Salat wajib lima kali sehari-semalam sangat dianjurkan agar dilaksanakan di masjid secara

\footnotetext{
${ }^{49}$ Asshalaatu 'imaadud din (Hadits).
} 
Otoritas Dan Gerakan Keagamaan Daengguru..

berjamaah. $^{50}$ Bahkan, salah satu di antara salat yang wajib itu, yakni salat Jum'at wajib dilaksanakan secara berjamaah di masjid. Oleh karena itu, G. F. Pijper benar ketika dia mengatakan bahwa siapa saja yang ingin menyelidiki kehidupan keagamaan di salah satu daerah di Indonesia, dia harus mulai dengan mempelajari masjid. ${ }^{51}$

Dilihat dari segi fungsinya, masjid adalah pusat peribdatan dan pusat komunikasi. ${ }^{52}$ Sebagai pusat peribadatan masjid berfungsi sebagai sarana dalam rangka pelaksanaan ajaran Islam yang berkaitan dengan hablumminallah (hubungan manusia dengan Allah). Sedangkan, sebagai pusat komunikasi, masjid berfungsi sebagai sarana dalam rangka pelaksanaan ajaran Islam yang berkaitan dengan hablummninnas (hubungan manusia dengan sesama manusia).

Sepanjang sejarah umat Islam, penekanan dan penjabaran terhadap kedua fungsi utama masjid tersebut berbeda-beda antara satu waktu dari waktu lainnya dan antara satu tempat dari tempat lainnya. Itulah sebabnya sehingga fungsi masjid digambarkan dengan penggambaran yang berbeda-beda. H. A. R. Gibb ${ }^{53}$ menggambarkannya sebagai centre for divine service and state institution. Sidi Gazalba ${ }^{54}$ menggambarkannya sebagai pusat ibadan dan kebudayaan Islam. H. J. De Graaf ${ }^{55}$ menggambarkannya sebagai pusat pertemuan orang-orang beriman dan menjadi lambang kesatuan jema'at.

Masjid di Hindia Belanda yang merupakan pusat penyiaran agama Islam yang berpengaruh terhadap kehidupan penduduk secara keseluruhan, menurut Snouck Hurgronje ${ }^{56}$ lebih berfungsi daripada di kebanyakan negara Islam lainnya. Mesjid hampir dapat ditemukan di tempat-tempat pemukiman dan pusat-pusat pemerintahan. Masjid di pusat pemerintahan biasanya disebut sebagai Masjid Agung.

Gambaran umum yang dikemukakan Hurgronje tentang masjid Hindia Belanda tersebut mewakili juga Sulawesi Selatan. Di Sulawesi Selatan pada awal abad ke-20 mesjid telah terdapat di semua pusat kerjaan dan di hampir semua kerajaan bawahan. Di beberapa kampung besar yang merupakan bagian dari kerajaan bawahan, juga telah terdapat masjid. Dan, di hampir semua kampung telah terdapat langgar.

Penanggung jawab pengurusan dan pemakmuran masjid di pusat kerajaan adalah petta kali atau daengta kaliya. Penanggung jawab pengurusan dan pemakmuran masjid di kerajaan bawahan atau ke-gallarrang-an adalah imang bate atau imang limpo. Penanggung jawab pengurusan dan pemakmuran masjid di kampung adalah guru atau mang kampung. Dalam melaksanakan tugasnya yang berkaitan dengan pengurusan dan pemakmuran masjid, masing-masing penanggungjawab di bantu oleh beberpa orang hatte, bidala, dan doja.

Berbeda dari Jawa yang memiliki masjid di daerah pardikan yang dikuasai dan diurus sepenuhnya oleh ulama bebas atau kiai pesantren, di Sulawsesi Selatan hingga awal abad ke-20 tidak terdapat masjid yang diurus oleh ulama di luar birokrasi pemerintahan. Semua masjid

\footnotetext{
${ }^{50}$ Salat berjamaah di masjid 27 kali lebih utama utama daripada salat sendiri di rumah (Hadits).

${ }^{51}$ Lihat: Pijper (1984: 14-15).

${ }^{52}$ Lihat: Rahim (1998: 205).

${ }^{53}$ Lihat: Gibb (1953).

${ }^{54}$ Lihat: Gazalba (1975).

${ }^{55}$ Lihat: de Graaf (1985: 27).

${ }^{56}$ Lihat: Hurgronje (1983: 14).

88 |Falasifa, Vol. 11 Nomor 2 September 2020
} 
dikuasai dan diurus oleh para parewa sara'. Pelaksanaan ibadah di dalamnya pun menjadi tanggung jawab ulama parewa sara. Tidak ada masjid tanpa parewa sara'. Tidak ada kegiatan di dalam masjid yang dapat berjalan tanpa parewa sara'.

Terkait dengan fungsi masjid sebagai sarana penghubunga antara manusia dengan Tuhannya (babkuminallah) dan sarana penghubung dengan sesama manusia (bablumminnas), maka kegiatan yang dilaksanakan di dalamnya pun pada garis besarnya dapat dibedakan ke dalam kegiatan peribadatan dan kegiatan keagamaan lainnya. Kegiatan peribadatan adalah kegiatan yang bersifat ritual berupa ibadah dalam rangka hubungan langsung antara manusia selaku makhluk dengan Allah selaku khalik. Ibadah tersebut meliputi salat wajib lima waktu, salat Jum'at, salat sunat tarawih, salat dua hari raya (Idul Fitri dan Idul Adha), salat jenazah, dan salat-alat sunat lainnya. Selain yang disebutkan terakhir, semuanya dilaksanakan secara berjamah, oleh di bawah pimpinan seorang imam. Oleh karena itu maka tanggungjawab pelaksanaannya berada di tangan parewa sara'.

Menjelang salat lima waktu dilaksanakan, doja memukul beduk sebagai pertanda waktu salat telah masuk. Selanjutnya bidala naik ke menara masjid ${ }^{57}$ untuk mengumandangkan azan memanggil umat ke masjid bersalat jamaah. Mendengar panggilan salat, umat pun berbondongbondonglah menuju masjid. Setibanya di masjid, mereka melaksanakan salat sunat tahiyatul masjid dan salat sunat rawatib secara sendiri-sendiri. Setelah diperkirakan bahwa jamaah sudah hadir semuanya, imang atau hatte pun datanglah untuk memimpin salat jamaah. Bersamaan dengan kedatangannya itu, diserukanlah iqamat oleh bidala atau salah seorang jamaah sebagai perintah untuk berdiri dan bersiap-siap melaksanakan salat yang segera akan dilaksanakan. Pada saat itu, imam tanpillah ke mihrab masjid sambil mengucapkan kalimat "assalatu jaamiah rabimakumullah (mari kita sama-sama melaksanakan salat jamaah semoga Allah merahmati kita semua)" diteruskan dengan melafalkan niat sebagai imam atas salat wajib yang akan dilaksanakan. Selesai memberi melaksanakan salat imam dan jamaah tidak langsung berdiri tidak langsung bubar, mereka duduk sejenak untuk beristigfar, berzikir dan berdo'a dipimpin oleh imam dan diikuti oleh para makmum. ${ }^{58}$

Pada hari jumat, setelah waktu lohol masuk, doja menabuh beduk sesuai dengan aturan. Setelahnya, azan pertama dikumandangkan dan setelah khatib naik ke mimbar memberi salam kepada para jamaah, azan kedua pun dikumandangkan. Pejabat Parewa sara' yang bertugas mengumandangkan azan adalan bidala. Sedangkan yang bertindak sebagai khatib adalah hatte. Dan, yang bertindak sebagai imam adalah daengta kaliya di masjid pusat kerajaan, imang limpo/imangbate di masjid kerajaan bawahan atau guru/imang kampung di masjid kampung.

Khotbah jumat yang dibaca adalah bahasa Arab. Dalam pembukaan khotnahnyanya, sesudah menyampaikan pujian kepada Allah dan salawat salawat kepada Nabi Muhammd saw, khatib menyampaikan juga doa keselamatan buat raja. Do'a buat raja ini berlaku di semua masjid, mulai dari masjid di pusat kerajaan sampai masjid di kampung-kampung. Kegiatan

\footnotetext{
${ }^{57}$ Azan dikumandangkan dari tempat yang tinggi supaya suara azan terdengar jauh ke pelosok sekitar masjid. Dan untuk membantu mengeraskan suaranya, bidala biasanya menggunakan corong suara yang terbuat dari seng atau bahan lainnya.

${ }^{58}$ Istigfar, zikir, dan do'a pada salat subuh dan magrib biasanya lebih panjang daripada salat-salat lainnya.
} 
keagamaan lainnya yang dilaksanakan di masjid adalah kegiatan dakwah dan pendidikan, berupa antara lain: upacara peringatan Maulid Nabi Muhammad saw, arrate juma', ceramah-ceramah agama, angngaji korang, dan angngaji kitta.

Setiap tahun, pada bulang maudu (bulan Rabiul Awal) umat Islam menyelenggarakan perintan maulid Nabi Muhammad saw, yang disebut maudu, yang pelaksanaannya dipusatkan di masjid. Bagian terpenting dari maudu tersebut adalah kanre maudu, yaitu bakul kecil berhiaskan telur dan kembang kertas warna-warni yang didalamnya berisi kanre pamatara (nasi setengah matang), songkola (nasi kukus dari beras ketan hitam), kaddo minynya (nasi kukus dari beras ketan putuh yang diolesi minyak goreng yang mengandung bermacam-macam rempah-rempah), ayam goreng, teluar, dan bermacam-macam lauk-pauk.

Kelihatannya kanre maudu tersebut sangat sederhana saja, tetapi perlu dijelaskan bahwa untuk membuatnya diperlukan waktu persiapan yang sangat lama. Sekurang-kurangnya 40 hari sebelum dipotong, ayam yang akan dijadikan bagian dari kanre maudu sudah harus dikurung dalam kandang. Tujuannya supaya ayam yang akan "dipersembahkan" kepada Nabi Muhammad saw bersih dari memakan najis, terutama kotoran manusia. ${ }^{59}$

Sama halnya dengan ayam, nasi (yang terdiri atas kanre pamatara, songkolo, dan kaddominnya) yang akan dijadikan kanre maudu juga harus diurus secara khusus. Pengurusan secara khusus ini didasari oleh suatu kepercayaan bahwa nasi yang akan dipersembahkan sebagai kanre maudu tidak boleh berasal dari sisa manusia dan binatang, khusnya ayam. Oleh karena itu maka sejak diturunkan dari tempat penyimpanannya (di lotong atau lumbung), padi yang diniatkan untuk menjadi nasi yang akan dipersembahkan sudah harus diperlakukan khusus. Di tempat jemuran harus dijaga ketat agar jangan ada yang dimakan oleh ayam demikian pula di lesung tempat menumbuknya, tidak boleh ada yang terbuang lalu dimakan oleh ayam. Dimakan ayam mengandung pengertian bahwa yang dipersembahkan sebagai kanre maudu adalah sisanya ayam. Beras yang diperoleh dari padi yang diurus khusus tadi tidak boleh ada yang dimasak. Sebab kalau dimasak sebagian berarti kanre maudu yang nantinya akan dipersembahkan tersebut adalah sisa manusia.

Kanre maudu tersebut diletakkan di sekitar mihrab dan mimbar mesjid sejara berjejer yang jumlahnya tergantung pada banyaknya jamaah masjid yang turut berpartisipasi dalam peringatan maulid tersebut. Setelah kanre maudu dipersipakan diadakanlah upacara maudu, yang intinya adalah pembacaan Kitab Barazanji. Cara membaca kitab baransanji, dalam peringatan maulid hampir sama dengan cara membaca dalam upacara-upacara keagamaan lauinnya, yaitu dibaca secara tartil dan dilagukan dengan sedikit menambah atau mengurangi dari ucapan aslinya yang disebut rate. Setelah acara selesai, telur warna-warni yang ditusuk dengan lidi dan menjadi hiasan kanre maudu biasanya diperebutkan oleh anak-anak yang menghadiri upacara tersebut. Sementara nasi yang sudah dirateki (dibacakan Kitab Al-Barzanji atasnya), dibagikan kembali kepada yang telah menyetor dengan sistem pertukaran, sehingga tidak ada seorang pun

\footnotetext{
${ }^{59}$ Oleh karena masyarakat, pada umumnya belum menggunakan wc sebagai tempat membuang kotoran, maka kotoran manusia terkadang berserakan di tempat ayam mencari makanan. semak-semak sekitar rumah mereka seringkali menjadi santapan lesat bagi ayam, padahal yang paling tidak dibiarkan dimakan adalah kotoran manusia. itu berDulu kotoran manusia.

90 |Falasifa, Vol. 11 Nomor 2 September 2020
} 
yang boleh mengambil kanre maudunya sendiri. Kecuali upacara keagamaan yang diselenggarakan di masjid tersebut, parewa sara juga bertugas memimpin penyelenggaraan upacara-upacara keagamaan lainnya yang diselenggarak oleh anggota masyarakat di rumah mereka masing, seperti: assuro maca, assikiri (Arrate) Juma', appabarasanji (Apparate), dan assongkabala.

\section{DAFTAR PUSTAKA}

Mustaqim Pabbajah, Religiusitas dan Kepercayaan Masyarakat Bugis-Makasar, dalam Jurnal al-Ulum Vol. 12 No. 2 Tahun 2012.

Jubba, dkk., Kompromi Islam dan Adat pada Praktik Keagamaan Muslim Bugis di Sulawesi Selatan, dalam JSW: Jurnal Sosiologi Walisongo Vol. 2 No. 2 Tahun 2018.

Sabara Nuruddin, Islam dalam Tradisi Masyrakat Lokal di Sulawesi Selatan, dalam Mimikri: Jurnal Agama dan Kebudayaan Vol. 4 No. 1 Tahun 2018.

Mardi Adi Armin, Islam \& Tradisi Budaya di Sulawesi Selatan, dalam Jurnal Adabiyah Vol. 10 No. 2 Tahun 2010.

Ismail Suardi Wekke, Islam dan Adat: Tinjauan Akulturasi Budaya dan Agama dalam Masyarakat Bugis, dalam Analisis: Jurnal Studi Keislaman Vol. 13 No. 1 Tahun 2013.

Darmawijaya \& Irwan Abbas, Sejarah Mubammadiyah di Sulawesi Selatan 1926-1942, dalam Jurnal Lektur Keagamaan Vol. 12 No. 2 Tahun 2014.

La Sakka, Historiografi Islam di Kerajaan Bantaeng, dalam Jurnal al-Qalam Vol. 20 No. 1 Tahun 2014.

Anzar Abdullah, Islamisasi di Sulawesi Selatan dalam Perspektif Sejarah, dalam Paramita: Historical Studies Journal Vol. 26 No. 1 Tahun 2016.

Rahmawati, Perspektif Baru dalam Proses Penyebaran Islam di Kerajaan Bone Sulawesi Selatan Indonesia pada Abad ke 17, dalam Rihlah: Jurnal Sejarah dan Kebudayaan Vol. 3 No. 1 Tahun 2015.

Taufik Abdullah, Pengantar, dalam Taufik Abdullah, Agama dan Perubahan Sosial, V-XV, (Jakarta: Rajawali Pers, 1983)

Puji Siswadi, Politik Islamisasi Kerajaan Gowa-Tallo Terbadap Tiga Kerajaan Tellumpoccoe Bone, Soppeng, Wajo) pada Abad 17, dalam Rihlah: Jurnal Sejarah dan Kebudayaan Vol. 4 No. 1 Tahun 2016. 